\title{
İnfertil Obez Kadınlarda Obezitenin Yönetiminde Kullanılan Yöntemlerin Obstetrik Sonuçlara Etkisi: Sistematik Derleme ve Meta-Analiz*
}

\section{The Effect of Methods Used in the Management of Obesity in Infertile Obese Women on Obstetric}

Outcomes: A Systematic Review and Meta-Analysis

Döndü Kurnazi, Zekiye Karaçam ${ }^{\text {ii }}$

iUz. Ebe, Küçükçekmece illçe Sağlık Müdürlüğü. https://orcid.org/0000-0002-0613-7919

iiProf. Dr., Aydın Adnan Menderes Üniversitesi, Sağlık Bilimleri Üniversitesi Ebelik Bölümü. https://orcid.org/0000-0002-0419-8961

öz

\begin{abstract}
Amaç: Bu çalışma, infertil obez kadınlarda obezitenin yönetiminde kullanılan yöntemlerin obstetrik sonuçlara etkisinin belirlemesi amacı ile yapılmıştır.

Yöntem: Çalışma sistematik derlemede ve meta-analiz deseninde yapılmıştır. Taramalar Şubat-Mart 2021 tarihleri arasında, obesity* AND infertility* AND weight control*AND weight reduction* kelime grupları ile PubMed, Ulusal Tez Merkezi, DergiPark, MEDLINE, the Cochrane Library ve EBSCO arama motorlarından yapılmıştır. Araştırmaların metodolojik kalitesi Joanna Briggs Institute tarafından geliştirilen deneysel, yarı deneysel ve kesitsel çalışmalar için Kritik Değerlendirme Kontrol Listeleri ile değerlendirilmiştir. Veriler meta-analiz yöntemleri ile sentez edilmiştir.

Bulgular: Çalışmaya 2010-2021 yıllarında yayımlanmış 19 araştırma dâhil edilmiştir. Araştırmaların toplam örneklem hacmi 3253'tür. Metaanaliz sonuçlarında, müdahale grubunda gebelik oluşumunun 2.12 (OR: 2.12, p=0.002), spontan gebeliğin 2.19 (OR: 2.19, $p<0.001$ ), canlı doğum oranının 1,5 (OR: 1.50, p=0.04) ve abortus gelişme olasılı̆ının 1.58 (OR: 1.58, $p=0.01$ ) kat daha fazla olduğu bulunmuştur. Çalışmaların birleştirilmiş sonuçları, kullanılan yöntemlerin, beden kitle indeksi ( $p=0.0003)$, kadın başına düşen obstetrik maliyet $(p=0.0007)$ ve doğum ağılığında ( $p=0.04)$ istatistiksel olarak anlamlı azalmaya neden olduğunu ve yardımlı gebelik, çoğul gebelik, ektopik gebelik, sezaryen doğum, preterm doğum, laserasyon, doğum sonu kanama, preeklemsi, gestasyonel diyabet, gestasyonel hipertansiyon, HELLP sendromu, APGAR<7 ve konjenital anomali üzerine etkili olmadığını göstermiştir.

Sonuç: Bu çalışmada, obez infertil kadınlarda kilo yönetiminde kullanılan yöntemlerin, kilo kaybı, gebelik oluşumu, canlı doğum, spontan gebelik ve abortus oranını arttırdığı, obstetrik komplikasyonlar, kadın ve bebek sağlığı ile ilgili sonuçları etkilemediği, obstetrik maliyeti düşürdüğü sonuçları açığa çıkarılmıştır.
\end{abstract}

Anahtar Kelimeler: Obezite, İnfertilite, Gebelik, Diyet, Egzersiz, Kilo kaybı

ABSTRACT

Aim: This study was conducted to determine the effects of the methods used in the management of obesity in infertile obese women on obstetric outcomes.

Method: The study was conducted in a systematic review and meta-analysis design. Searches were made between February and March 2021, using the word groups obesity* AND infertility* AND weight control*AND weight reduction* from PubMed, National Thesis Centre, DergiPark, MEDLINE, the Cochrane Library and, EBSCO search engines. The methodological quality of the studies was evaluated with the Critical Evaluation Checklists developed by the Joanna Briggs Institute. Data were synthesized by meta-analysis methods.

Results: For this study, the results of 19 studies published in 2010-2021 were compiled. The total sample size of the studies is 3253 . In the meta-analysis results, pregnancy occurs in the intervention group was 2.12 (OR: 2.12, $p=0.002$ ), spontaneous pregnancy was 2.19 (OR: 2.19 , $p<0.001$ ), live birth rate was 1.5 (OR: $1.50, p=0.04$ ), and the probability of developing abortion was $1.58(\mathrm{OR}: 1.58, p=0.01)$ times higher. The combined results of the studies showed that the methods used resulted in a statistically significant reduction in body mass index ( $p=0.0003)$, obstetric cost per woman ( $p=0.0007)$ and, birth weight $(p=0.04)$. In addition don't affect the results of obstetric complications.

Conclusion: In this study, it was revealed that the methods used in weight management in obese infertile women increase the rate of pregnancy formation, live birth, spontaneous pregnancy, and abortion, do not affect the results of obstetric complications, women and infant health.

Keywords: Obesity, Infertility, Pregnancy, Diet, Exercise, Weight loss

"Mersin Üniversitesi Tıp Fakültesi Lokman Hekim Tıp Tarihi ve Folklorik Tıp Dergisi, 2022; 12 (1): 149-169

DOI: $10.31020 /$ mutftd.1003918

e-ISSN: 1309-8004, ISSN 1309-761X

Geliş Tarihi - Received: 02 Ekim 2021; Kabul Tarihi - Accepted: 29 Kasım 2021

Iletişim - Correspondence Author: Döndü Kurnaz <zsk2001@hotmail.com> 


\section{Giriş}

Dünya Sağlık Örgütü (DSÖ) obeziteyi, insan sağlığını olumsuz etkileyecek ölçüde aşırı yağ birikmesi sonucu oluşan bir hastalık olarak tanımlamaktadır. Obezitenin belirlenmesinde kullanılan en yaygın yöntem beden kitle indeksi (BKi) hesaplamasıdır. Yetişkinlerde BKi'nin $25 \mathrm{~kg} / \mathrm{m}^{21}$ nin üzerinde olması aşırı kilolu ve 30 $\mathrm{kg} / \mathrm{m}^{2 \prime}$ nin üzerinde olması da obez olarak kabul edilmektedir. ${ }^{1}$ DSÖ'ye göre obezite sorunu salgın boyutlarına ulaşmışır ve 2017 yılında dört milyondan fazla insan aşırı kilolu veya obez olması nedeniyle hayatını kaybetmiştir. Dünyada 18 yaş ve üstü yetişkinlerin \%39'u fazla kilolu ve \%13'ü obezdir. Bu oran kadınlarda 2014 yılında \%15 iken, daha sonraki iki yılda iki kattan daha fazla artış göstermiştir. ${ }^{1}$ Türkiye' de ise $15-49$ yaş aralığındaki kadınların \%59'u fazla kilolu ve \%30'u obezdir. ${ }^{2}$

Infertilite, 12 ay veya daha uzun süreli düzenli korunmasız cinsel ilişkiden sonra gebe kalamama ile tanımlanan erkek veya kadın üreme sistemi hastalığıdır. Bazıları infertiliteyi yaşam kalitesi sorunu olarak algılasa da DSÖ infertiliteyi dünya çapında toplumsal bir sağlık sorunu olarak göstermekte ve 15-49 yaş arasındaki çiftlerin yaklaşık \%10-15' ini etkilediğini bildirmektedir. ${ }^{3}$ Ülkemizde ise evli çiftler arasında infertilite oranı \%10-20 arasında değişmektedir. ${ }^{4}$

Infertilite erkek veya kadın üreme sistemine ilişkin bir dizi farklı faktöre bağlı olarak gelişebilir. Ancak her zaman infertilitenin nedenlerini üreme sistemi ile açıklamak mümkün olmamaktadır. ${ }^{3}$ DSÖ yayınlarında ve diğer ilgili literatürde obezite de infertilite nedenleri arasında gösterilmektedir..$^{3-5}$

Gelişmekte olan ülkelerde infertilite yaygın ve ciddi bir endişe kaynağıdır. Kanıtlar, infertilite sonuçlarının genellikle hafife alındığını göstermektedir. Fakat sonuçlar ciddi ekonomik kayıplar, sosyal izolasyon, cinayet ve intihara kadar uzanmaktadır. ${ }^{5,6}$ ABD Hastalık Kontrol ve Önleme Merkezi, infertilite algılama, önleme ve yönetimi için bir eylem planı geliştirmiş ve bu planda, infertiliteye neden olan sorunları daha iyi anlama ve ele alma intiyacının önemini vurgulamıştır. Bu planda, özellikle doğurganlığı sağlama ve sürdürmeye yardımcı olabilecek sağlıklı davranışları teşvik edilmekte, doğurganlığı tehdit edebilecek çevresel ve iyatrojenik etkenlere maruz kalmanın azaltılmasını önermektedir. ${ }^{6}$

Gebelik öncesi dönemde obez olan kadınlarda; infertilite, gebelik oluşması ve devamında başarııızık, doğum kontrol başarısızlığı gibi üreme dönemi sorunlarına daha sık rastlanmaktadır. ${ }^{5}$ Yapılan bir çalışmada kilo kaybının, yüksek spontan gebe kalma oranının yanı sıra, ovulasyon indüksiyon tedavisi ve gebelik sonucunu iyileştirdiği rapor edilmiştir. ${ }^{7}$ Yine 40 çalışmanın dâhil edildiği bir sistematik derlemede de kadınlarda azaltılmış kalorili diyet ve egzersiz müdahaleleri ile kilo kaybının ovulasyon oluşumunda iyileşme sağladığı bildirilmiştir. $^{8}$

Gebelik planlayan obez kadınların kilo vermelerini sağlamak için bireye özel beslenme, egzersiz ve yaşam tarzı değişikliği programlarının planlanması ve uygulanması gerekmektedir. ${ }^{9} \mathrm{Bu}$ kapsamda sağlık çalışanlarının üreme dönemindeki kadın ve ailelerinin sağlığının korunması, geliştirilmesi ve izlemine ilave olarak, obezitenin üreme üzerindeki risklerinin önlenmesi ve yönetiminde önemli sorumlulukları bulunmaktadır.

Literatürde infertil obez kadınlarda obezitenin yönetiminin gebelik sonuçlarını inceleyen sekiz adet randomize kontrollü deneysel çalışmanın dâhil edildiği bir sistematik derleme ve meta-analiz çalışması bulunmaktadır. Ancak literatürde daha fazla deneysel çalışma ve genişörneklem grupları ile yapılan gözlemsel araştırmaların da bulunduğu görülmüş, bu konuya ilişkin daha kapsamlı verilerin açığa çıkarılmasına gereksinim duyulmuş ve bu çalışmanın yapılmasına karar verilmiştir. Elde edilen bilgilerin obez infertil kadınlara yönelik sunulacak sağlık hizmetlerinin geliştirilmesine ve konuya ilişkin bilgi birikimine katkı oluşturması beklenmektedir. 


\section{Araştırmanın Amacı ve Araştırma Soruları}

Bu sistematik derleme ve meta-analizde, birincil çalışmalara dayalı olarak, infertil obez kadınlarda obezitenin yönetiminde kullanılan yöntemlerin obstetrik sonuçlara etkisinin belirlemesi amaçlanmıştır. Araştırmada yanıtlanması hedeflenen sorular şunlardır;

1. İnfertil obez kadınlarda obezitenin yönetimi için kullanılan yöntemler nelerdir?

2. Infertil obez kadınlarda obezitenin yönetiminde kullanılan yöntemlerin BKi değişimi, gebelik, doğum, obstetrik maliyet ve anne-bebek sağlığı sonuçları üzerindeki etkileri nelerdir?

\section{Gereç ve Yöntemler}

$\mathrm{Bu}$ çalışma sistematik derleme ve meta-analiz niteliğinde gerçekleştirilmiştir. Çalışma protokolünün oluşturulması ve yazımında PRISMA Bildirimi (PRISMA Statement-Sistematik Derleme ya da Meta-analiz Araştırma Raporunun Yazımında Bulunması Gereken Maddelerle ilgili Kontrol Listesi) takip edilmiştir. ${ }^{10}$ Tekrarı önlemek, planlama aşamasında tamamlanmış çalışmalarla karşılaştırma yapabilmek ve bias riskini azaltmak amacı ile PROSPERO girişi yapılmış ve 08.04.2021 tarihli CRD42021241555 olan kayıt numarası alınmıştır.

\section{Uygunluk Kriterleri}

Bu sistematik derleme için uygun olan araştırmalar aşağıdaki kriterlere (PICOS) göre belirlenmiştir;

$\checkmark$ Çalışma grubu (P: Patient): Obez infertil kadınlar.

$\checkmark$ Müdahale (I: Intervention): Obezite yönetiminde kullanılan yöntemler (diyet programları, egzersiz ve yaşam tarzı değişiklikleri gibi çalışmalarla tanımlandığı gibi).

$\checkmark$ Karşılaştırma (C: Comparison): Müdahale yapılmayan kadınlar ve ön-test sonuçları.

$\checkmark$ Sonuçlar (C: Outcomes): Obezite yönetiminin sonuçları (BKi değişimi, gebelik, doğum, obstetrik maliyet, anne-bebek sağlığı sonuçları).

$\checkmark$ Çalışma deseni (S: Study design): Sistematik derlemeye infertil obez kadınlarda obezitenin yönetimini rapor eden deneysel, yarı deneysel ve kesitsel çalışmalar alınmıştır. Çalışmaya 2010-2021 yıllarında yapılmış, Türkçe ve İngilizce olarak yayımlanan çalışmalar dahil edilmiştir.

Türkçe ve İngilizce dışındaki dillerde yayınlanan ve tam metnine erişilemeyen çalışmalar analiz kapsamı dışında tutulmuştur. Metodolojik kaliteye dayalı olarak herhangi bir çalışma hariç tutulmamıştır.

\section{Tarama Stratejisi}

Bu sistematik derlemede taramalar Şubat-Mart 2021 tarihleri arasında PubMed, Ulusal Tez Merkezi, DergiPark, MEDLINE, the Cochrane Library ve EBSCO arama motorlarından yapılmıştır. Taramalarda "obesity* AND infertility* AND weight control*AND weight reduction* kelime grupları kullanılmıştır. İngilizce anahtar kelimeler "Medical Subject Headings (MESH)" e uygun olarak belirlenmiştir. PubMed üzerinden yapılan bir tarama örneği; ("obesity"[MeSH Terms] OR "obesity"[All Fields]) AND ("infertility"[MeSH Terms] OR "infertility"[All Fields]) AND ("2010/01/01"[PubDate]: "2021/12/31"[PubDate]) şeklindedir. Ilave taramalar için sistematik derlemeye dâhil edilen araştırmalar ve daha önce yapılan sistematik derlemelerin referans listeleri kontrol edilmiştir.

\section{Çalışmaların Seçimi}

Bu sistematik derleme ve meta-analiz için çalışmaların seçiminde taramalarda tekrar eden çalışmaların çıkarılması, başlık, özet ve tam metne göre seçilerek belirlenmiştir. Herhangi bir çalışma hakkında görüş 
farklılığı olduğunda her iki araştırmacının da katıldığı bir oturumda tartışma yoluyla uzlaşmaya varılmıştır. Sistematik derlemede taranan araştırmaların sayısı, uygun olanlar ve derlemeye dâhil edilenler, dışlanan araştırmalar ve dışlama nedenleriyle birlikte PRISMA akış şemasında verilmiştir (Şekil 1).
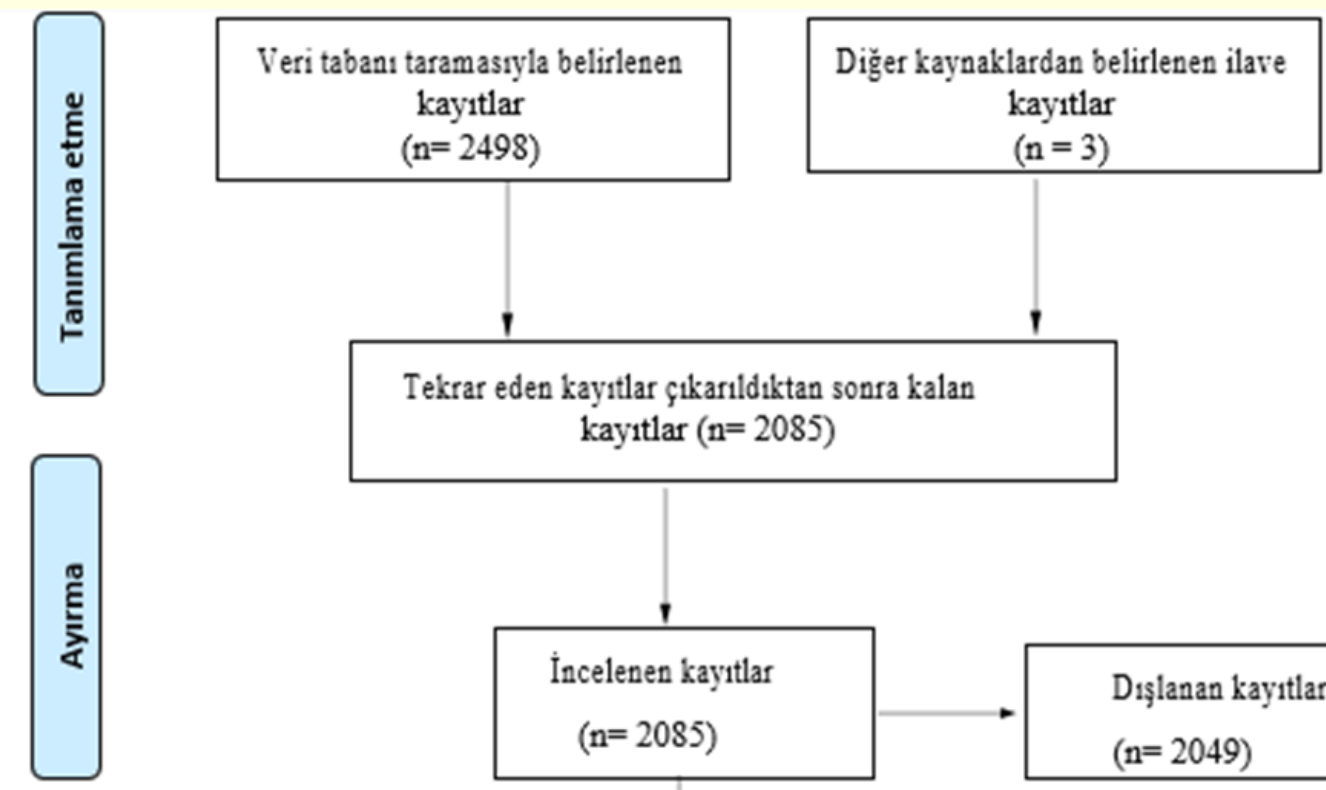

Tekrar eden kayitlar çikarıldiktan sonra kalan kayitlar $(n=2085)$
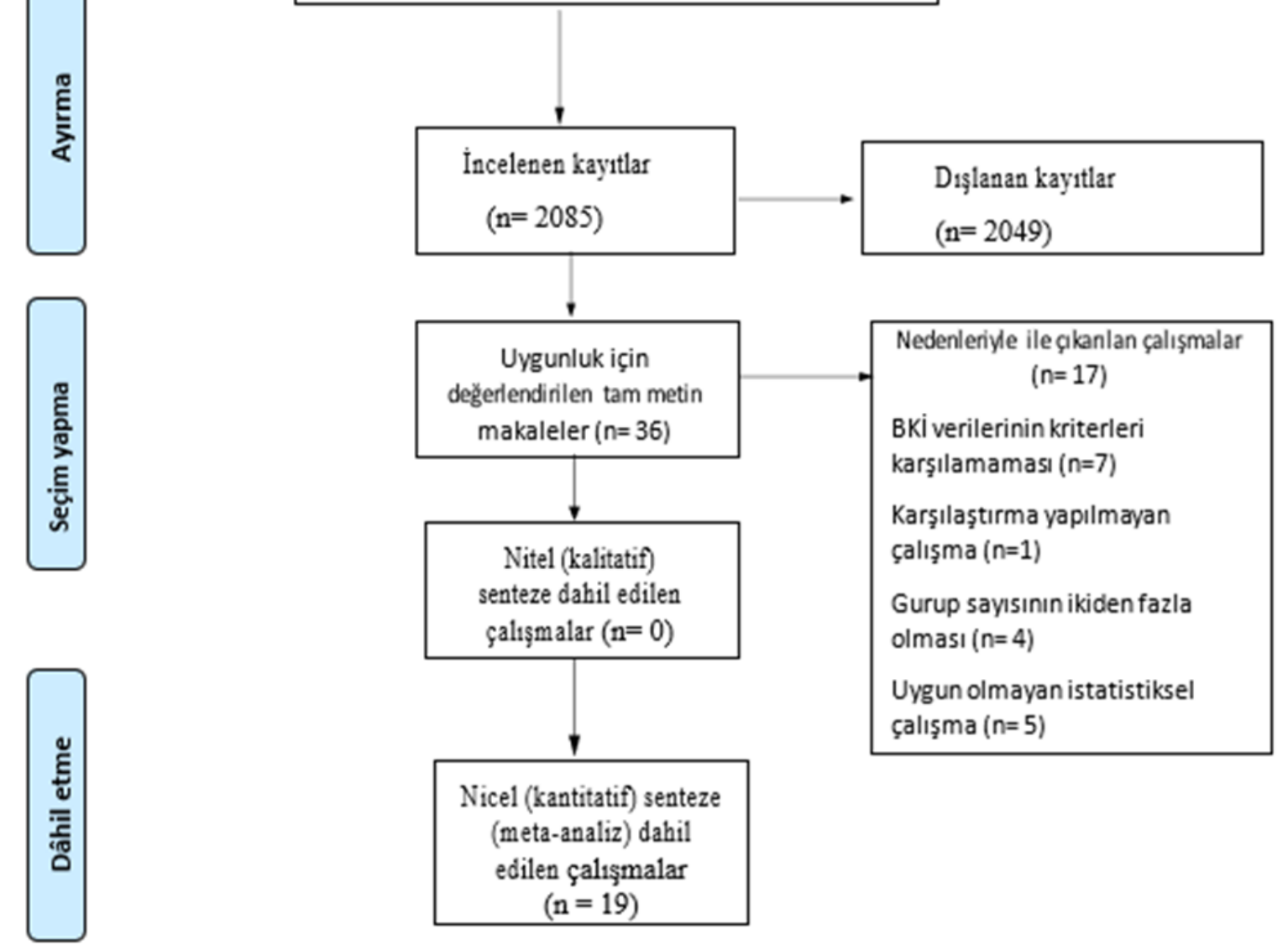

Şekil 1. PRISMA Akış Şeması

\section{Çalışmaların Metodolojik Kalitesinin Değerlendirilmesi}

Bu sistematik derleme ve meta-analize dahil edilen araştırmaların metodolojik kalitesinin incelenmesinde Joanna Briggs Institute (JBI) tarafından geliştirilen deneysel, yarı deneysel ve kesitsel çalışmalar için Kritik Değerlendirme Kontrol Listeleri kullanılmıştır. ${ }^{11} \mathrm{Bu}$ kontrol listelerinin yarı deneysel çalışmalar için olanında dokuz, deneysel çalışmalar için olanında 13 ve kesitsel çalışmalar için olanında sekiz soru yer almaktadır. Sorular "Evet, Hayır, Belirsiz ve Uygulanmaz" seçenekleri ile cevaplanmaktadır. Araştırmaya dahil edilen çalışmaların metodolojik kalite düzeyi, maddelerin \%50'sinden azı "evet" olarak değerlendirildi ise "vasat", maddelerin \%51-80'i arasında "evet" olarak değerlendirildi ise "orta kalite" ve maddelerin \%80'inden fazlası "evet" olarak değerlendirildi ise "iyi kalite" olarak kabul edilmiştir. 


\section{Verilerin Çekilmesi}

Araştırma verilerinin elde edilmesinde JBI tarafından geliştirilen ve internet sayfasından elde edilen veri çekme aracı, üzerinde çalışmaya uygun değişiklikler yapılarak kullanılmıştır. ${ }^{12} \mathrm{Bu}$ veri çekme aracı ile sistematik derleme ve meta-analize dâhil edilen araştırmaların yapıldığı yer ve yılı, yöntemi, veri kaynağı, örneklem hacmi, obezitenin yönetimi için kullanılan yöntemler ve başlıca bulguları ile ilgili veriler elde edilmiştir.

\section{Pilot Çalışma}

Bu sistematik derleme ve meta-analizde olası bias riskini önlemek için tarama yapma, makalelerin seçimi, veri çekme ve dâhil edilen makalelerin kalite değerlendirme işlemleri araştırmacıların katıldığı oturumlarda her aşama öncesinde pilot çalışma yapılarak ortak yol haritası oluşturulmuştur. Ayrıca olası hataları önlemek için tüm bu aşamalar her iki araştırmacı tarafından bağımsız olarak yapılmış ve elde edilen çalışmalar ortak oturumlarda tek bir metin üzerinde birleştirilmiştir.

\section{Verilerin Sentezi}

Çalışmalardan elde edilen verilerin meta-analiz yapılarak birleştirilmiştir. Meta-analiz için Review Manager 5.4.1 (The Nordic Cochrane Center, Kopenhag, Danimarka) kullanılmışır. Çalışmalar arasındaki heterojenlik, Cochran'ın Q testi ve Higgins' ${ }^{2}$ kullanılarak değerlendirilmiştir. I' ${ }^{2}$ nin $\% 50$ 'den fazlasının önemli heterojenliği gösterdiği kabul edilmiştir. Kategorik değişkenler için "Odds Oranı" ve sürekli değişkenler için "Standardize Ortalama Fark" hesaplanmıştır. Tüm testler two-tailed hesaplarında 0,05'ten küçük bir p değeri istatistiksel olarak anlamlı kabul edilmiştir.

\section{Bulgular}

\section{Tarama bulguları}

Bu çalışmada ilk tarama sonucunda 2498 kayıta ulaşılmıştır. Sırası ile tekrar eden kayıtların çıkarılması, başlık ve özet göre yapılan inceleme sonucunda tam metinde incelenmek üzere 36 araştırma belirlenmiştir. Bu araştırmaların tam metinlerinin dâhil etme ölçütlerine göre incelenmesi sonucunda 19 çalışma analize alınmıştır (Şekil 1).

\section{Çalışmaların ve katılımcıların özellikleri}

Sistematik derlemeye alınan araştırmaların 13'ü randomize kontrollü deneysel ve bir tanesi yarı deneysel çalışmadır. ${ }^{13-17,20,21-23,26-28,30,31}$ Bunun dışında üç tanesi kesitsel ve iki tanesi de kohort niteliktedir. ${ }^{18,19,24,25,29}$ Ayrıca bu çalışmada protokolü önceden yayınlanmış ve sonuçları ön sonuç olarak verilmiş bir çalışmanın verileri de kullanılmıştır. ${ }^{14}$ Çalışmaların yapııdı̆̆ı ülkelerin, İtalya, Hollanda, İskandinav Ülkeleri, Avusturalya, Amerika Birleşik Devletleri, Brezilya, Kanada, İspanya, Fransa, Türkiye ve Norveç olduğu saptanmıştır. Araştırmaların toplam örneklem hacmi 3253 (müdahale grubu: 1482; kontrol grubu: 1598; tek grup: 245)'tür (Tablo 1). 
Tablo 1. Çalışmaların Özellikleri ve Başlıca Verileri

\begin{tabular}{|c|c|c|c|c|c|c|c|}
\hline $\begin{array}{l}\text { Yazar ve yıl / } \\
\text { Ülke }\end{array}$ & $\begin{array}{l}\text { Çalışmanın } \\
\text { yapıldığı yıl }\end{array}$ & $\begin{array}{l}\text { Çalışma } \\
\text { deseni }\end{array}$ & $\begin{array}{l}\text { Örneklem } \\
\text { hacmi }\end{array}$ & BKi & Anne yaşı & $\begin{array}{l}\text { Müdahale } \\
\text { türü / } \\
\text { süresi }\end{array}$ & $\begin{array}{l}\text { Çalışma bulguları } \\
\text { Müdahale ve Kontrol } \\
\text { / *Müdahale öncesi ve } \\
\text { Müdahale sonrası }\end{array}$ \\
\hline $\begin{array}{l}\text { Becker ve ark. } \\
2015 / \\
\text { Brezilya }^{13}\end{array}$ & 2012- 2013 & RCT & $\begin{array}{l}\text { Müdahale: } \\
14 \\
\text { Kontrol: } 12\end{array}$ & $\begin{array}{l}\text { Müdahale: } \\
28.67 \pm 0.60 \\
\text { Kontrol: } \\
28.82 \pm 0.98\end{array}$ & $\begin{array}{l}\text { Müdahale: } \\
31.36 \pm \\
0.89 \\
\text { Kontrol: } \\
31.25 \pm 0.78\end{array}$ & $\begin{array}{l}\text { Diyet / } 12 \\
\text { hafta }\end{array}$ & $\begin{array}{l}\text { Gebelik: } 3 / 14 \text { ve } 0 / 12 ; \\
\text { Canlı doğum: } 3 / 14 \text { ve } \\
0 / 12 ; \text { BKi değişimi: - } \\
1.95 \pm 0.45 \text { ve } 0.3 \pm \\
0.31\end{array}$ \\
\hline $\begin{array}{l}\text { Duval ve ark. } \\
\text { 2015/ } \\
\text { Kanada14 }^{14}\end{array}$ & 2011 & $\mathrm{RCT}$ & $\begin{array}{l}\text { Müdahale: } \\
24 \\
\text { Kontrol: } 31\end{array}$ & $\begin{array}{l}\text { İki grup: } \\
39.9 \pm 7.6\end{array}$ & $\begin{array}{l}\text { İki grup: } \\
30.5 \pm 4.8\end{array}$ & $\begin{array}{l}\text { Yaşam } \\
\text { tarzı } \\
\text { değişikliği } \\
\text { / } 6 \text { ay }\end{array}$ & $\begin{array}{l}\text { Gebelik: } 19 / 24 \text { ve } \\
\text { 13/31; Spontan } \\
\text { gebelik: } 12 / 24 \text { ve 4/31; } \\
\text { Yardımlı gebelik: } 7 / 24 \\
\text { ve } 9 / 31 ; \text { Canlı doğum: } \\
\text { 15/24 ve } 12 / 31 ; \text { BKi } \\
\text { değişimi:-6.9 } \pm 1.4 \text { ve - } \\
3.4 \pm 0.2\end{array}$ \\
\hline $\begin{array}{l}\text { Einarsson ve } \\
\text { ark. 2017/ } \\
\text { İskandinav } \\
\text { ülkeleri' }\end{array}$ & 2010-2016 & $\mathrm{RCT}$ & $\begin{array}{l}\text { Müdahale: } \\
152 \\
\text { Kontrol: } \\
153\end{array}$ & $\begin{array}{l}\text { Müdahale: } \\
28.7 \pm 4.30 \\
\text { Kontrol: } \\
28.8 \pm 4.10\end{array}$ & $\begin{array}{l}\text { Müdahale: } \\
31.5 \pm 4.3 \\
\text { Kontrol: } \\
31.7 \pm 4.1\end{array}$ & $\begin{array}{l}\text { Diyet / } 16 \\
\text { hafta }\end{array}$ & $\begin{array}{l}\text { Gebelik: 66/152 ve } \\
\text { 56/153; Spontan } \\
\text { gebelik:13/152 ve } \\
\text { 9/153; Yardımlı } \\
\text { gebelik: 53/152 ve } \\
\text { 47/153; Ektopik } \\
\text { gebelik: } 1 / 66 \text { ve } 1 / 56 ; \\
\text { Abortus:12/152 ve } \\
\text { 8/153; Canlı doğum: } \\
\text { 45/152 ve } 42 / 153 ; \\
\text { Tekil doğum: } 45 / 66 \text { ve } \\
\text { 41/56; ikiz doğum: } 0 \\
\text { ve } 1 / 56 ; \text { BKi değişim: - } \\
3.25 \pm 2.42 \text { ve } 0.44 \pm \\
0.72\end{array}$ \\
\hline $\begin{array}{l}\text { Einarsson ve } \\
\text { ark. 2019/ } \\
\text { İskandinav } \\
\text { ülkeleri' }\end{array}$ & 2010-2016 & $\mathrm{RCT}$ & $\begin{array}{l}\text { Müdahale: } \\
160 \\
\text { Kontrol: } \\
157\end{array}$ & $\begin{array}{l}\text { Müdahale: } \\
32.8 \pm 1.3 \\
\text { Kontrol: } \\
32.9 \pm 4.4\end{array}$ & $\begin{array}{l}\text { Müdahale: } \\
31.4 \pm 4.7 \\
\text { Kontrol: } \\
30.7 \pm 3.9\end{array}$ & $\begin{array}{l}\text { Diyet / } 12 \\
\text { hafta }\end{array}$ & $\begin{array}{l}\text { Gebelik: } 45 / 160 \text { ve } \\
\text { 41/157; Canlı doğum: } \\
\text { 45/160 ve 41/157; } \\
\text { Normal doğum: 32/45 } \\
\text { ve 31/41; } \\
\text { Sezaryen:13/45 ve } \\
\text { 10/41; Preterm } \\
\text { Doğum: } 3 / 45 \text { ve } 1 / 41 ; \\
\text { Preeklemsi: } 5 / 45 \text { ve } \\
\text { 4/41; Gestasyonel } \\
\text { diyabet: } 1 / 45 \text { ve } 2 / 41 ; \\
\text { Gestasyonel } \\
\text { hipertansiyon: } 1 / 45 \text { ve } \\
\text { 2/41; Postpartum } \\
\text { kanama: } 2 / 45 \text { ve } 5 / 41 ; \\
\text { APGAR<7 (5. dak): } 0 \text { ve } \\
\text { 1/41; Konjenital } \\
\text { anomali: } 3 / 45 \text { ve } 2 / 41 ; \\
\text { Doğum ağırlığı (gr): } \\
3486 \pm 523 \text { ve } 3584 \pm \\
\text { 509 }\end{array}$ \\
\hline $\begin{array}{l}\text { Espinos ve } \\
\text { ark. } 2017 / \\
\text { İspanya }{ }^{17}\end{array}$ & $2013-2015$ & $\mathrm{RCT}$ & $\begin{array}{l}\text { Müdahale: } \\
21 \\
\text { Kontrol: } 20\end{array}$ & $\begin{array}{l}\text { Müdahale: } \\
34.6 \pm 3 \\
\text { Kontrol: } 34 \\
\pm 4.1\end{array}$ & $\begin{array}{l}\text { Müdahale: } \\
32 \pm 3.20 \\
\text { Kontrol: } \\
32.9 \pm 3.9\end{array}$ & $\begin{array}{l}\text { Diyet ve } \\
\text { egzersiz / } \\
12 \text { hafta }\end{array}$ & $\begin{array}{l}\text { Gebelik: } 12 / 21 \text { ve } \\
\text { 7/20; Canlı doğum: } \\
\text { 11/21 ve } 6 / 20 \text {; Çoğul } \\
\text { gebelik: } 1 / 14 \text { ve } 1 / 6 ; \\
\text { Abortus: } 1 / 21 \text { ve } 1 / 20\end{array}$ \\
\hline $\begin{array}{l}\text { Goldman ve } \\
\text { ark. 2016/ } \\
\text { ABD }^{18}\end{array}$ & $2002-2012$ & $\begin{array}{l}\text { Retrospektif } \\
\text { Kesitsel }\end{array}$ & $\begin{array}{l}\text { Müdahale: } \\
55 \\
\text { Kontrol: } 19\end{array}$ & & $\begin{array}{l}\text { İki grup: } \\
39.7 \pm 9.8\end{array}$ & $\begin{array}{l}\text { Bariatrik } \\
\text { cerrahi }\end{array}$ & $\begin{array}{l}\text { Gebelik: } 44 / 55 \text { ve } \\
\text { 16/19; Canlı doğum: } \\
\text { 29/55 ve 15/19; } \\
\text { Preterm doğum: } 3 / 44 \\
\text { ve 2/16; Abortus: }\end{array}$ \\
\hline
\end{tabular}




$\begin{array}{lllllll}\begin{array}{l}\text { Grzegorczyk } \\ \text { ve ark. }\end{array} & 2012-2016 & \text { Retrospektif } & \text { Müdahale: } & \text { Müdahale: } & \text { Müdahale: } & \text { Bariatrik } \\ \text { 2020/Fransa19 } & & \text { Kohort } & 83 & 28.9 \pm 4.7 & 33.1 \pm 4.4 & \text { cerrahi } \\ & & & \text { Kontrol: } 83 & \text { Kontrol: } & \text { Kontrol: } & \\ & & & 37.7 \pm 2.8 & 32.8 \pm 4\end{array}$

\begin{tabular}{lll}
$\begin{array}{l}\text { Kaya ve ark. } \\
\text { 2016/ } \\
\text { Türkiye }\end{array}$ & 2014-2015 & RCT \\
$\begin{array}{l}\text { Kiel ve ark. } \\
\text { 2018/ } \\
\text { Norveç }\end{array}$ & $2016-2017$ & RCT \\
$\begin{array}{l}\text { Milone ve } \\
\text { ark. 2017/ } \\
\text { Italya22 }\end{array}$ & $2005-2015$ & $\begin{array}{l}\text { Yarı } \\
\text { Deneysel }\end{array}$ \\
\hline
\end{tabular}

Moran ve ark. 2011

2011/

Avustralya ${ }^{23}$

Musella ve 2003-2008

ark. 2011/

İtalya ${ }^{24}$

Diyet ve
egzersiz /
5-9 hafta
Bariatrik
cerrahi

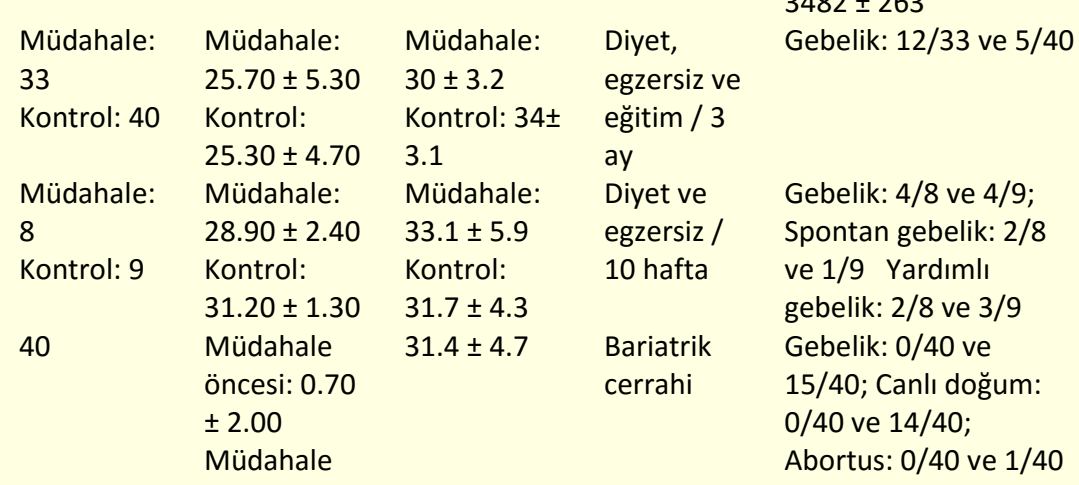

Müdahale: Müdahale:

$18 \quad 34 \pm 4.5$

Kontrol: 20 Kontrol:

$33.9 \pm 4.4$

Retrospektif

Kesitsel

23

$41 \pm 2,7$ Abortus: $0 / 40$ ve $1 / 40$

Müdahale: $33.8 \pm 3.5$ Kontrol: $32.5 \pm 3.3$ $31 \pm 4.8$

Gebelik: $12 / 18$ ve 8/20; Canlı doğum: $7 / 18$ ve $5 / 20$

* Gebelik: 0/23 ve 15/23; Canlı doğum: 0
11/55 ve 2/19; Doğum ağırlığı: $2983.78 \pm$ 510.01 ve $3583.51 \pm$ 518.93

Gebelik: $31 / 83$ ve 23/83; Canlı doğum: $19 / 83$ ve $10 / 83$; Abortus: $12 / 83$ ve 13/83; ikiz doğum: $3 / 19$ ve $0 / 10$; Vajinal doğum: $13 / 19$ ve $7 / 10$; Sezaryen doğum: 6/31 ve 3/23; Doğum ağırlığı: $2753 \pm 734$ ve $3482 \pm 263$ ve $14 / 23$; Spontan gebelik: 0 ve 11/15; Yardımlı gebelik: 0 ve 4/15; Abortus: $0 / 23$ ve $1 / 23$

\begin{tabular}{|c|c|c|c|c|c|c|}
\hline $\begin{array}{l}\text { Musella ve } \\
\text { ark. 2012/ } \\
\text { İtalya } 25\end{array}$ & 2002-2008 & $\begin{array}{l}\text { Retrospektif } \\
\text { Kesitsel }\end{array}$ & 110 & $43.9 \pm 4.1$ & $29.3 \pm 3.9$ & $\begin{array}{l}\text { Bariatrik } \\
\text { cerrahi }\end{array}$ \\
\hline $\begin{array}{l}\text { Mutsaerts ve } \\
\text { ark. } 2016 \\
\text { /Hollanda26 }\end{array}$ & 2009 & $\mathrm{RCT}$ & $\begin{array}{l}\text { Müdahale: } \\
280 \\
\text { Kontrol: } \\
284\end{array}$ & $\begin{array}{l}\text { Müdahale: } \\
36 \text { (33.4- } \\
38.2) \\
\text { Kontrol: } 36 \\
\text { (33.5-38.2) }\end{array}$ & $\begin{array}{l}\text { Müdahale: } \\
29.7 \pm 4.5 \\
\text { Kontrol: } \\
29.8 \pm 4.6\end{array}$ & $\begin{array}{l}\text { Diyet, } \\
\text { egzersiz ve } \\
\text { eğitim / } 6 \\
\text { ay }\end{array}$ \\
\hline
\end{tabular}

* Gebelik: 0/110 ve 69/110

Gebelik: $175 / 280$ ve 186/284; Yardımlı gebelik: 102/280 ve 140/284; Spontan gebelik: $73 / 280$ ve 46/284; Çoğul gebelik: $6 / 280$ ve $9 / 284$; Ektopik gebelik: 4/280ve 7/284; Abortus: $41 / 280$ ve 27/284; Canlı doğum: $123 / 280$ ve $153 / 284$; Preterm doğum: $17 / 123$ ve $22 / 153$; Vajinal doğum: 71/123 ve 89/153; Müdahaleli doğum: $13 / 123$ ve 24/153; Sezaryen doğum: 39/175 ve 40/186; Tekil doğum: $76 / 280$ ve $100 / 284$; 


\begin{tabular}{|c|c|c|c|c|c|c|c|}
\hline $\begin{array}{l}\text { Oers ve ark. } \\
2017 / \\
\text { Hollanda }^{27}\end{array}$ & 2009-2012 & RCT & $\begin{array}{l}\text { Müdahale: } \\
280 \\
\text { Kontrol: } \\
284\end{array}$ & $\begin{array}{l}\text { Müdahale: } \\
36 \text { (33.4- } \\
38.2) \\
\text { Kontrol: } 36 \\
\text { (33.5-38.2) }\end{array}$ & $\begin{array}{l}\text { Müdahale: } \\
29.7 \pm 4.5 \\
\text { Kontrol: } \\
29,8 \pm 4,6\end{array}$ & $\begin{array}{l}\text { Yaşam } \\
\text { tarzı } \\
\text { değişikliği } \\
\text { / } 6 \text { ay }\end{array}$ & $\begin{array}{l}16 / 154 \\
\text { Gebelik: } 126 / 280 \text { ve } \\
\text { 154/284; Tekil gebelik: } \\
\text { 120/280 ve } 145 / 284 ; \\
\text { Çoğul gebelik: } 6 / 280 \\
\text { ve } 9 / 284 \text {; Canlı doğum: } \\
76 / 280 \text { ve } 100 / 284\end{array}$ \\
\hline $\begin{array}{l}\text { Oers ve ark. } \\
2016 / \\
\text { Hollanda }^{28}\end{array}$ & 2009-2012 & RCT & $\begin{array}{l}\text { Müdahale: } \\
280 \\
\text { Kontrol: } \\
284\end{array}$ & $\begin{array}{l}\text { Müdahale: } \\
36 \text { (33.4- } \\
38.2) \\
\text { Kontrol: } 36 \\
\text { (33.5-38.2) }\end{array}$ & $\begin{array}{l}\text { Müdahale: } \\
29.7 \pm 4.5 \\
\text { Kontrol: } \\
29.8 \pm 4,6\end{array}$ & $\begin{array}{l}\text { Yaşam } \\
\text { tarzı } \\
\text { değişikliği } \\
\text { / } 6 \text { ay }\end{array}$ & $\begin{array}{l}\text { Gebelik: } 225 / 280 \text { ve } \\
265 / 284 ; \text { Canlı doğum: } \\
\text { 149/280 ve } 165 / 284 ; \\
\text { Ortalama maliyet }(€): \\
4324 \pm 4276 \text { ve } 5603 \pm \\
4632\end{array}$ \\
\hline $\begin{array}{l}\text { Palomba ve } \\
\text { ark. 2014/ } \\
\text { İtalya }\end{array}$ & 2009-2012 & $\begin{array}{l}\text { Gözlemsel } \\
\text { Kohort }\end{array}$ & $\begin{array}{l}\text { Müdahale: } \\
41 \\
\text { Kontrol: } \\
175\end{array}$ & $\begin{array}{l}\text { Müdahale: } \\
33.3 \pm 2.7 \\
\text { Kontrol: } \\
32.7 \pm 2.5\end{array}$ & $\begin{array}{l}\text { Müdahale: } \\
37.1 \pm 3.0 \\
\text { Kontrol: } \\
37.3 \pm 3.6\end{array}$ & $\begin{array}{l}\text { Egzersiz / } 6 \\
\text { ay }\end{array}$ & $\begin{array}{l}\text { Gebelik: } 16 / 41 \text { ve } \\
\text { 28/175; Abortus: } 6 / 41 \\
\text { ve 15/175; Yardımlı } \\
\text { gebelik: } 12 / 41 \text { ve } \\
\text { 16/175; Spontan } \\
\text { gebelik:4/41 ve } \\
\text { 12/175; Canlı doğum: } \\
\text { 10/16 ve 13/28; Çoğul } \\
\text { gebelik:1/41 ve } 2 / 175\end{array}$ \\
\hline $\begin{array}{l}\text { Rothberg ve } \\
\text { ark. 2016/ } \\
\text { ABD }\end{array}$ & $2013-2015$ & RCT & $\begin{array}{l}\text { Müdahale: } \\
6 \\
\text { Kontrol:5 }\end{array}$ & $\begin{array}{l}\text { Müdahale: } \\
41 \pm 4.0 \\
\text { Kontrol: } 41 \\
\pm 4.0\end{array}$ & $\begin{array}{l}\text { Müdahale: } \\
33 \pm 5.0 \\
\text { Kontrol: } 30 \\
\pm 4.0\end{array}$ & $\begin{array}{l}\text { Egzersiz / } \\
12 \text { hafta }\end{array}$ & $\begin{array}{l}\text { Gebelik: } 3 / 6 \text { ve } 0 / 5 \\
\text { Canlı doğum:3/6 ve } \\
0 / 5\end{array}$ \\
\hline $\begin{array}{l}\text { Sim ve ark. } \\
\text { 2014/ } \\
\text { Avusturya }^{31}\end{array}$ & 2007-2011 & RCT & $\begin{array}{l}\text { Müdahale: } \\
27 \\
\text { Kontrol: } 22\end{array}$ & $\begin{array}{l}\text { Müdahale: } \\
35.1 \pm 3.8 \\
\text { Kontrol: } \\
38.0 \pm 5.2\end{array}$ & $\begin{array}{l}\text { Müdahale: } \\
32.9 \pm 3.3 \\
\text { Kontrol: } \\
32.8 \pm 3.1\end{array}$ & $\begin{array}{l}\text { Diyet, } \\
\text { egzersiz ve } \\
\text { eğitim / } 12 \\
\text { hafta }\end{array}$ & $\begin{array}{l}\text { Gebelik: } 13 / 27 \text { ve } 3 / 22 ; \\
\text { Yardımlı gebelik: } 10 / 27 \\
\text { ve } 3 / 22 ; \text { Spontan } \\
\text { gebelik: } 3 / 27 \text { ve } 0 ; \\
\text { Abortus: } 5 / 27 \text { ve } 1 / 22 ; \\
\text { Canlı doğum: } 12 / 27 \text { ve } \\
\text { 3/22; Gestasyonel } \\
\text { diyabet: } 0 / 13 \text { ve } 1 / 22 ; \\
\text { Gestasyonel } \\
\text { hipertansiyon: } 0 / 27 \text { ve } \\
\text { 1/22; Preeklemsi: } 1 / 13 \\
\text { ve } 0 / 3 ; \text { BKi değişim; } \\
\text { Müdahale: }-2.4 \pm 1.6 \text { ve } \\
\text { Kontrol: }-0.6 \pm 6.3\end{array}$ \\
\hline
\end{tabular}




\section{Obezitenin yönetiminde kullanılan yöntemler}

Bu sistematik derleme ve meta-analiz kapsamına alınan çalışmalardan beş tanesinde beriatrik cerrahi, dört tanesinde diyet ve egzersiz, üç tanesinde diyet, üç tanesinde bireyselleştirilmiş yaşam tarzı değişikliği, iki tanesinde egzersiz ve iki tanesinde diyet, egzersiz ve eğitim müdahaleleri kullanılmıştır (Tablo 1).

\section{Kalite değerlendirme bulguları}

Randomize kontrollü deneysel nitelikte çalışmaların kalite değerlendirme düzeyi dokuz çalışma için orta ve dört çalışma için iyi olarak saptanmıştır. Kesitsel ve kohort çalışmalarının kalite değerlendirme düzeyi de bir çalışmada vasat, iki çalışmada orta ve iki çalışmada da iyi, yarı deneysel olan bir çalışmanın ise orta olarak belirlenmiştir (Tablo 2).

Tablo 2. Çalışmaların Kalite Değerlendirme Skorları

\begin{tabular}{|c|c|c|c|c|c|c|c|c|c|c|c|c|c|c|}
\hline \multirow[b]{2}{*}{ Çalışmalar } & \multicolumn{13}{|c|}{ JBI Randomize Kontrollü Çalışmalar İçin Kritik Değerlendirme Kontrol Listesi Soruları } & \multirow{2}{*}{$\begin{array}{l}\text { Çalışm } \\
\text { aların } \\
\text { Kalite } \\
\text { Skoru }\end{array}$} \\
\hline & S1 & S2 & S3 & S4 & S5 & S6 & S7 & S8 & S9 & S10 & S11 & S12 & S13 & \\
\hline Becker ve ark. 2015 & $\mathrm{E}$ & $\mathrm{E}$ & $\mathrm{E}$ & U & $U$ & $\mathrm{H}$ & E & $E$ & $E$ & $E$ & $E$ & $E$ & $E$ & $\begin{array}{l}\text { Orta } \\
(\% 77)\end{array}$ \\
\hline Duval ve ark. 2015 & $E$ & $E$ & $E$ & $U$ & $U$ & $\mathrm{H}$ & $E$ & $E$ & $E$ & $\mathrm{E}$ & $E$ & $E$ & $E$ & $\begin{array}{l}\text { Orta } \\
(\% 77)\end{array}$ \\
\hline $\begin{array}{l}\text { Einarsson ve ark. } \\
2017\end{array}$ & $E$ & $E$ & $E$ & $\mathrm{U}$ & $U$ & $E$ & $E$ & $E$ & $E$ & $\mathrm{E}$ & $\mathrm{E}$ & $E$ & $E$ & $\begin{array}{l}\text { İyi } \\
\text { (\%85) }\end{array}$ \\
\hline $\begin{array}{l}\text { Einarsson ve ark. } \\
2019\end{array}$ & $E$ & $\mathrm{E}$ & $\mathrm{E}$ & $U$ & $U$ & $E$ & $E$ & $\mathrm{E}$ & $E$ & $\mathrm{E}$ & $\mathrm{E}$ & $\mathrm{E}$ & $\mathrm{E}$ & $\begin{array}{l}\text { İyi } \\
\text { (\%85) }\end{array}$ \\
\hline Espinos ve ark. 2017 & $\mathrm{E}$ & $E$ & B & $U$ & $U$ & $\mathrm{H}$ & $E$ & $\mathrm{E}$ & $E$ & $\mathrm{E}$ & $\mathrm{E}$ & $E$ & $E$ & $\begin{array}{l}\text { Orta } \\
(\% 69)\end{array}$ \\
\hline Kaya ve ark. 2016 & B & B & $E$ & $U$ & $U$ & $\mathrm{H}$ & $E$ & $E$ & $E$ & $\mathrm{E}$ & $\mathrm{E}$ & $E$ & $E$ & $\begin{array}{l}\text { Orta } \\
(\% 62)\end{array}$ \\
\hline Kiel ve ark. 2018 & $E$ & $\mathrm{E}$ & $E$ & $U$ & $U$ & $\mathrm{E}$ & $E$ & $\mathrm{E}$ & $E$ & $\mathrm{E}$ & $\mathrm{E}$ & $E$ & $E$ & $\begin{array}{l}\text { İyi } \\
\text { (\%85) }\end{array}$ \\
\hline Moran ve ark.2011 & $E$ & $\mathrm{E}$ & $E$ & $U$ & $U$ & $\mathrm{H}$ & B & $\mathrm{E}$ & $E$ & $\mathrm{E}$ & $\mathrm{E}$ & $E$ & $\mathrm{E}$ & $\begin{array}{l}\text { Orta } \\
(\% 69)\end{array}$ \\
\hline $\begin{array}{l}\text { Mutsaerts ve ark. } \\
2016\end{array}$ & $E$ & $E$ & $E$ & $U$ & $U$ & $\mathrm{H}$ & $E$ & $\mathrm{E}$ & $E$ & $E$ & $\mathrm{E}$ & $E$ & $E$ & $\begin{array}{l}\text { Orta } \\
(\% 77)\end{array}$ \\
\hline Oers ve ark. 2016 & $\mathrm{E}$ & $E$ & $\mathrm{E}$ & $U$ & $U$ & $\mathrm{H}$ & $E$ & $\mathrm{E}$ & $E$ & $\mathrm{E}$ & $\mathrm{E}$ & $E$ & $E$ & $\begin{array}{l}\text { Orta } \\
(\% 77)\end{array}$ \\
\hline Oers ve ark. 2017 & B & B & $E$ & U & $U$ & $\mathrm{H}$ & $E$ & $\mathrm{E}$ & $E$ & $E$ & $\mathrm{E}$ & $E$ & $E$ & $\begin{array}{l}\text { Orta } \\
(\% 62)\end{array}$ \\
\hline Rothberg ve ark. 2016 & $E$ & $E$ & $E$ & $U$ & $U$ & $\mathrm{H}$ & $E$ & $E$ & $E$ & $E$ & $\mathrm{E}$ & $E$ & $E$ & $\begin{array}{l}\text { Orta } \\
(\% 77)\end{array}$ \\
\hline Sim ve ark. 2014 & $E$ & $\mathrm{E}$ & $E$ & $U$ & $U$ & $E$ & $E$ & $E$ & $E$ & $E$ & $\mathrm{E}$ & $E$ & $E$ & $\begin{array}{l}\text { İyi } \\
\text { (\%85) }\end{array}$ \\
\hline \multirow[t]{2}{*}{ Soru Kalite Skoru } & $\% 85$ & $\% 85$ & $\% 92$ & $\% 00$ & $\% 00$ & $\% 31$ & $\% 92$ & $\% 100$ & $\% 100$ & $\% 100$ & $\% 100$ & $\% 100$ & $\% 100$ & \\
\hline & \multicolumn{14}{|c|}{ JBI Yarı Deneysel Çalışmalar İçin Kritik Değerlendirme Kontrol Listesi Soruları } \\
\hline Milone ve ark. 2017 & $\mathrm{E}$ & $\mathrm{U}$ & $\mathrm{U}$ & $\mathrm{H}$ & $\mathrm{E}$ & $\mathrm{E}$ & $\mathrm{E}$ & $\mathrm{E}$ & $\mathrm{E}$ & & & & & $\begin{array}{l}\text { Orta } \\
(\% 67)\end{array}$ \\
\hline \multirow[t]{2}{*}{ Soru Kalite Skoru } & $\% 100$ & $\% 00$ & $\% 00$ & $\% 00$ & $\% 100$ & $\% 100$ & $\% 100$ & $\% 100$ & $\% 100$ & & & & & \\
\hline & \multicolumn{14}{|c|}{ JBI Kesitsel Çalışmalar İçin Kritik Değerlendirme Kontrol Listesi Soruları } \\
\hline Musella ve ark. 2011 & $\mathrm{E}$ & $\mathrm{H}$ & $\mathrm{H}$ & $\mathrm{H}$ & $\mathrm{H}$ & $\mathrm{H}$ & $\mathrm{E}$ & $E$ & & & & & & $\begin{array}{l}\text { Vasat } \\
\text { (\%38) }\end{array}$ \\
\hline Musella ve ark. 2012 & $E$ & $\mathrm{H}$ & $\mathrm{H}$ & $E$ & $E$ & $E$ & $E$ & $\mathrm{E}$ & & & & & & $\begin{array}{l}\text { Orta } \\
(\% 75)\end{array}$ \\
\hline Goldman ve ark. 201 & $\mathrm{E}$ & $\mathrm{E}$ & $\mathrm{H}$ & $\mathrm{H}$ & $\mathrm{E}$ & $E$ & $E$ & $\mathrm{E}$ & & & & & & $\begin{array}{l}\text { Orta } \\
\text { (\%75) }\end{array}$ \\
\hline $\begin{array}{l}\text { Grzegorczyk ve ark. } \\
2020\end{array}$ & $E$ & $\mathrm{H}$ & $E$ & $E$ & $\mathrm{E}$ & $E$ & $E$ & $\mathrm{E}$ & & & & & & $\begin{array}{l}\text { İyi } \\
\text { (\%88) }\end{array}$ \\
\hline Palomba ve ark. 2014 & $E$ & $E$ & $E$ & $\mathrm{E}$ & $E$ & $E$ & $E$ & $\mathrm{E}$ & & & & & & $\begin{array}{l}\text { İyi } \\
\text { (\%100) }\end{array}$ \\
\hline Soru Kalite Skoru & $\% 100$ & $\% 40$ & $\% 40$ & $\% 60$ & $\% 80$ & $\% 80$ & $\% 100$ & $\% 100$ & & & & & & \\
\hline
\end{tabular}




\section{Meta-Analiz Bulguları}

\section{BKi ile ilgili meta-analiz bulguları}

Bu sistematik derleme ve meta-analizde incelenen dört araştırmada obez infertil kadınlarda uygulanan müdahalelerin BKi değişimi üzerine etkisi ile ilgili sonuçlar mevcuttu. ${ }^{13-15,31} \mathrm{Bu}$ çalışmaların birleştirilmiş sonuçlarında, gruplar arası farkın $-2.17 \mathrm{~kg} / \mathrm{m}^{2}$ olduğu ve bu sonucun istatistiksel olarak anlamlı olduğu saptanmıştır (SMD: $-2.71 \mathrm{~kg} / \mathrm{m}^{2}, 95 \%:-4.16--1,26, \mathrm{Z}=3.65, \mathrm{p}=0.003$, şekil 2).

\begin{tabular}{|c|c|c|c|c|c|c|c|c|c|c|c|}
\hline \multirow[b]{2}{*}{ Study or Subgroup } & \multicolumn{3}{|c|}{ Müdahale } & \multicolumn{3}{|c|}{ Kontrol } & \multicolumn{2}{|r|}{ Std. Mean Difference } & \multirow{2}{*}{\multicolumn{2}{|c|}{$\begin{array}{l}\text { Std. Mean Difference } \\
\text { IV, Random, } 95 \% \mathrm{Cl}\end{array}$}} & \\
\hline & Mean & SD & Total & Mean & SD & Total & Weight & IV, Random, $95 \% \mathrm{Cl}$ & & & \\
\hline Becker 2015 & -1.93 & 0.45 & 14 & 0.3 & 0.31 & 12 & $19.7 \%$ & $-5.51[-7.31,-3.71]$ & $\longmapsto$ & & \\
\hline Duval 2015 & -6.9 & 1.4 & 24 & -3.4 & 0.2 & 31 & $25.5 \%$ & $-3.69[-4.58,-2.80]$ & $\rightarrow-$ & & \\
\hline Einarsson 2017 & -3.25 & 2.42 & 152 & 0.44 & 0.72 & 153 & $27.9 \%$ & $-2.06[-2.34,-1.79]$ & & $\#$ & \\
\hline Sim 2014 & -2.4 & 1.6 & 27 & -0.6 & 6.3 & 22 & $27.0 \%$ & $-0.40[-0.97,0.16]$ & & $\rightarrow-1$ & \\
\hline Total $(95 \% \mathrm{Cl})$ & & & 217 & & & 218 & $100.0 \%$ & $-2.71[-4.16,-1.26]$ & & & \\
\hline \multicolumn{9}{|c|}{$\begin{array}{l}\text { Heterogeneity. } \text { Tau }^{2}=1.95 ; \mathrm{Chi}^{2}=58.63, \mathrm{df}=3(P<0.00001) ; \mathrm{I}^{2}=95 \% \\
\text { Test for overall effect } Z=3.65(P=0.0003)\end{array}$} & -4 & $\begin{array}{ccc}1 & 1 & 1 \\
-2 & 0 & 2 \\
\text { Müdahale } & \text { Kontrol }\end{array}$ & 4 \\
\hline
\end{tabular}

Şekil 2. Müdahale Ve Kontrol Gruplarının BKi İle İlgili Meta-Analiz Bulguları

\section{Gebelik ile ilgili meta-analiz bulguları}

Bu sistematik derlemede incelenen kontrol gruplu 16 çalışma bulunmaktadır. ${ }^{13-21,23,26-31}$ Ön test-son test kontrollü ise üç araştırmada obez infertil kadınlarda uygulanan kilo yönetim müdahalelerinin gebelik oluşumu üzerine etkisi ile ilgili sonuçlar bildirilmişti. ${ }^{22,24,25}$ Bu çalışmaların bulgularına dayalı yapılan meta-analizde obez infertil kadınlara uygulanan kilo yönetim müdahalelerinin gebelik oluşumunu istatistiksel olarak anlamı bir şekilde 2.12 kat arttırdığı tespit edilmiştir (OR: 2.12, 95\%: $1.32-3.43, Z=3.08, p=0.002$, Şekil 3). Çalışma desenine göre yapılan alt grup analizinde, kontrol gruplu çalışmaların birleştirilmiş sonuçları, gebelik oluşumunun 1.5 kat daha fazla olduğu ve bu farkın istatistiksel olarak anlamlı olduğunu göstermiştir (OR: 1.52, 95\%: $1.01-2.28, Z=2.01, p=0.04$, Şekil 3). Yine ön test-son test kontrollü çalışmaların birleştirilmiş sonuçları da müdahale sonrasında gebelik oluşumunun istatistiksel olarak anlamlı bir şekilde arttığını göstermiştir (OR: 118.33, 95\%: 22.68 - 617.31, Z=5.66, p<0.001, Şekil 3).

Bu çalışmada incelenen yedi araştırmada, obez infertil kadınlarda uygulanan kilo yönetim müdahaleleri sonrasında spontan gebelik oluşumu ile ilgili sonuç bulunmakta idi. ${ }^{14,15,21,24,26,29,31}$ Bu çalışmaların sonuçlarına dayalı yapılan meta-analizde, obez infertil kadınlara uygulanan müdahale sonrasında spontan gebelik gelişiminin istatistiksel olarak anlamlı bir şekilde 2.19 kat arttığı saptanmıştır (OR: 2.19, 95\%: 1.58 - 3.048, $\mathrm{Z}=4.72, \mathrm{p}<0.001$, şekil 3).

Bu sistematik derleme ve meta-analizde incelenen yedi araştırmada, obez infertil kadınlarda uygulanan kilo yönetim müdahalelerinin yardımlı gebelik üzerine etkisi ile ilgili sonuç bildirilmiştir. ${ }^{14,15,21,24,26,29,31} \mathrm{Bu}$ çalışmaların birleştirilmiş sonuçları, müdahale sonrasında, yardımlı gebelik oluşumunda 1.5 kat artış olduğu, ancak bu artışın istatistiksel olarak anlamlı olmadığını göstermiştir (OR: 1.50, 95\%: 0.75 - 3.03, Z=1.14, p=0.25, Şekil 3).

Bu sistematik derlemede incelenen dört araştırmada obez infertil kadınlarda uygulanan kilo yönetim müdahalelerinin çoğul gebelik üzerine etkisi ile ilgili sonuçlar rapor edilmişti. ${ }^{17,26,28,29}$ Bu sonuçlar ile yapılan meta-analizde, müdahale grubunda çoğul gebelik gelişiminin daha az olduğu, ancak bu bulgunun istatistiksel olarak anlamlı olmadığı saptanmıştır (OR: 0.74, 95\%: 0.37 - 1.47, Z=0.85, p=0.39, şekil 3). 
Gebelik oluşumu

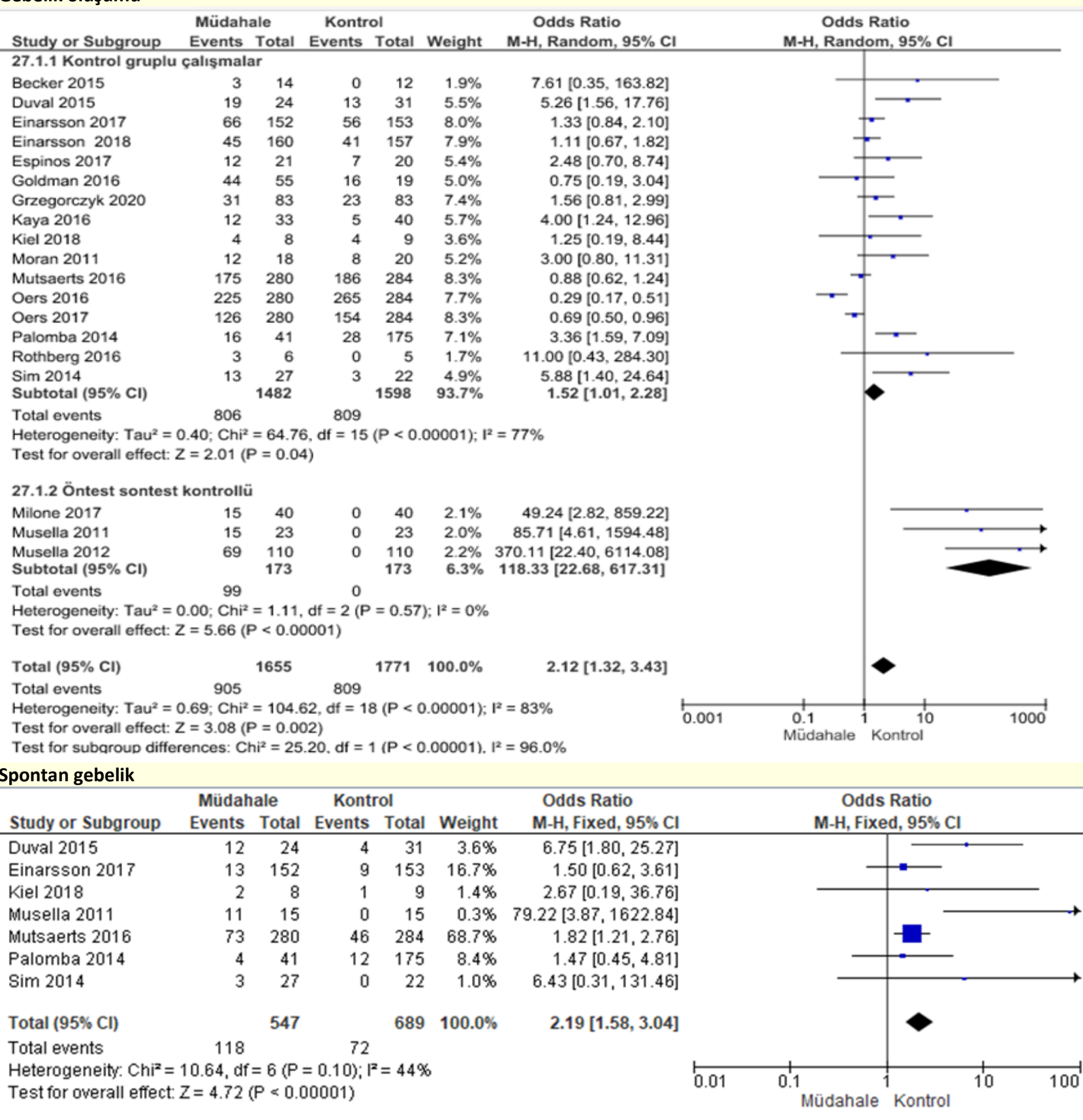

\begin{tabular}{|c|c|c|c|c|c|c|c|c|c|}
\hline \multicolumn{10}{|l|}{ Yardımlı gebelik } \\
\hline \multirow[b]{2}{*}{ Study or Subgroup } & \multicolumn{2}{|c|}{ Müdahale } & \multicolumn{2}{|c|}{ Kontrol } & \multirow[b]{2}{*}{ Weight } & \multirow{2}{*}{$\begin{array}{l}\text { Odds Ratio } \\
\text { M-H, Random, } 95 \% \mathrm{Cl}\end{array}$} & \multirow{2}{*}{\multicolumn{2}{|c|}{$\begin{array}{l}\text { Odds Ratio } \\
\text { M-H, Random, } 95 \% \mathrm{Cl}\end{array}$}} & \\
\hline & Events & Total & Events & Total & & & & & \\
\hline Duval 2015 & 7 & 24 & 9 & 31 & $14.3 \%$ & $1.01[0.31,3.25]$ & & & \\
\hline Einarsson 2017 & 53 & 152 & 47 & 153 & $21.5 \%$ & $1.21[0.75,1.95]$ & & & \\
\hline Kiel 2018 & 2 & 8 & 3 & 9 & $7.5 \%$ & $0.67[0.08,5.54]$ & & & \\
\hline Musella 2011 & 4 & 15 & 0 & 15 & $4.4 \%$ & $12.13[0.59,248.49]$ & & - & \\
\hline Mutsaerts 2016 & 102 & 280 & 140 & 284 & $22.7 \%$ & $0.59[0.42,0.83]$ & & $\rightarrow$ & \\
\hline Palomba 2014 & 12 & 41 & 16 & 175 & $17.7 \%$ & $4.11[1.76,9.59]$ & & $\longrightarrow$ & \\
\hline Sim 2014 & 10 & 27 & 3 & 22 & $11.9 \%$ & $3.73[0.88,15.83]$ & & & \\
\hline Total $(95 \% \mathrm{Cl})$ & & 547 & & 689 & $100.0 \%$ & $1.50[0.75,3.03]$ & & & \\
\hline Total events & 190 & & 218 & & & & & & \\
\hline \multicolumn{7}{|c|}{$\begin{array}{l}\text { Heterogeneity: } \text { Tau }^{2}=0.54 ; \mathrm{Chi}^{2}=26.46, \mathrm{df}=6(P=0.0002) ; \mathrm{I}^{2}=77 \% \\
\text { Test for overall effect: } Z=1.14(P=0.25)\end{array}$} & 0.002 & $\begin{array}{ccc}0.1 & 1 & 10 \\
\text { Müdahale } & \text { Kontrol }\end{array}$ & 500 \\
\hline
\end{tabular}


Çoğul gebelik

\begin{tabular}{|c|c|c|c|c|c|c|c|c|c|}
\hline \multirow[b]{2}{*}{ Study or Subgroup } & \multicolumn{2}{|c|}{ Müdahale } & \multicolumn{2}{|c|}{ Kontrol } & \multirow[b]{2}{*}{ Weight } & \multirow{2}{*}{$\begin{array}{c}\text { Odds Ratio } \\
\text { M-H, Fixed, } 95 \% \mathrm{Cl}\end{array}$} & \multirow{2}{*}{\multicolumn{2}{|c|}{$\begin{array}{c}\text { Odds Ratio } \\
\text { M-H, Fixed, } 95 \% \mathrm{Cl}\end{array}$}} & \\
\hline & Events & Total & Events & Total & & & & & \\
\hline Espinos 2017 & 1 & 21 & 1 & 20 & $5.1 \%$ & $0.95[0.06,16.29]$ & & & \\
\hline Mutsaerts 2016 & 6 & 280 & 9 & 284 & $45.5 \%$ & $0.67[0.23,1.91]$ & & & \\
\hline Oers 2017 & 6 & 280 & 9 & 284 & $45.5 \%$ & $0.67[0.23,1.91]$ & & & \\
\hline Palomba 2014 & 1 & 41 & 2 & 175 & $3.9 \%$ & $2.16[0.19,24.44]$ & & & \\
\hline Total $(95 \% \mathrm{Cl})$ & & 622 & & 763 & $100.0 \%$ & $0.74[0.37,1.47]$ & & & \\
\hline Total events & 14 & & 21 & & & & & & \\
\hline $\begin{array}{l}\text { Heterogeneity: } \mathrm{Chi}^{2}= \\
\text { Test for overall effect }\end{array}$ & $\begin{array}{l}0.85, \mathrm{df}= \\
Z=0.85\end{array}$ & $\begin{array}{l}3(P= \\
(P=0.3\end{array}$ & $\begin{array}{l}0.84) ; 1^{2}= \\
\text { 39) }\end{array}$ & & & & 0.001 & $\begin{array}{ccc}0.1 & 1 & 10 \\
\text { Müdahale Kontrol }\end{array}$ & 1000 \\
\hline
\end{tabular}

Şekil 3. Müdahale ve Kontrol Gruplarının Gebelik İle IIlgili Meta-Analiz Bulguları

\section{Doğum ile ilgili meta-analiz bulguları}

$\mathrm{Bu}$ sistematik derleme ve meta-analizde incelenen kontrol gruplu 14 ve ön test-son test kontrollü iki araştırmada obez infertil kadınlarda uygulanan müdahalenin canlı doğum sonuçları üzerine etkisi ile ilgili sonuçlar verilmişti. ${ }^{13-19,22-24,26-31}$ Yapılan meta-analizde müdahale sonrası canlı doğum oranını istatistiksel olarak anlamlı bir şekilde 1.5 kat arttı̆̆ı tespit edilmiştir (OR: 1.50, 95\%: 1.02 - 2.22, Z=2.05, p=0.04, şekil 4). Çalışma desenine göre yapılan alt grup analizinde, kontrol gruplu çalışmaların meta-analiz sonuçları, müdahale grubunda canlı doğum oranının 1.28 kat daha fazla olduğunu, fakat bu bulgunun istatistiksel olarak anlamlı olmadığını göstermiştir (OR: 1.28, 95\%: 0.90 - 1.81, Z=1.38, p=0.17, Şekil 4). Ancak, ön test-son test kontrollü çalışmalara dayalı yapılan meta-analizde, müdahale sonrası canlı doğum oranının istatistiksel olarak anlamlı bir şekilde arttığı belirlenmiştir (OR: 56.12, 95\%: 72.7 - 432.94, Z=3.86, p=0.0001, Şekil 4).

Bu sistematik derlemeye dahil edilen dört araştırmada obez infertil kadınlarda uygulanan müdahale sonrasında çoğul doğum görülmesi ile ilgili sonuçlar rapor edilmişti. ${ }^{15,19,23,26}$ Bu çalışmaların bulguları ile yapılan meta-analizde müdahalelerin çoğul doğum gelişiminde etkili olmadığı saptanmıştır (OR: 0.97, 95\%: 0.63 - 1.51, Z=0.12, p=0.91, Şekil 4). Bu sistematik derlemeye dâhil edilen üç araştırmada sezaryen doğum ile ilgili sonuçlar rapor edilmişti. ${ }^{16,19,26}$ Bu çalışmalara dayalı yapılan meta-analizde obez infertil kadınlara uygulanan kilo yönetim müdahalelerinin sezaryen doğum gelişiminde etkili olmadığı bulunmuştur (OR: 1.12, 95\%: 0.74 - 1.72, Z=0.54, $p=0.59$, Şekil 4).

Bu çalışmada incelenen bir araştırmada obez infertil kadınlarda uygulanan kilo yönetim müdahalesinin perineal laserasyon ile ilgisine ilişkin veri rapor edilmişti. ${ }^{26} \mathrm{Bu}$ çalışmada müdahale grubunda laserasyon gelişime olasılığının daha az olduğunu, ancak bu sonucun istatistiksel olarak anlamlı olmadığı saptanmıştır (OR: 0.24, 95\%: $0.03-2.07, \mathrm{Z}=1.30, \mathrm{p}=0.19$, Şekil 4).

Çalışmaya dâhil edilen iki araştırmada obez infertil kadınlarda uygulanan kilo yönetim müdahalelerinin doğum sonu kanama üzerine etkisi ile ilgili sonuçlar bildirilmişti. ${ }^{16,26}$ Bu çalışmaların meta-analiz sonuçları, müdahale grubunda doğum sonu kanama gelişiminin daha az olduğunu, fakat bu sonucun istatistiksel olarak anlamsız olduğunu göstermiştir (OR: 0.74, 95\%: 0.32 - 1.68, Z=0.73, p=0.47, Şekil 4). 
Canlı doğum

\begin{tabular}{|c|c|c|c|c|c|c|c|c|c|c|}
\hline \multirow[b]{2}{*}{ Study or Subgroup } & \multicolumn{2}{|c|}{ Müdahale } & \multicolumn{2}{|c|}{ Kontrol } & \multirow[b]{2}{*}{ Weight } & \multirow{2}{*}{$\begin{array}{l}\text { Odds Ratio } \\
\text { M- } \mathrm{H}, \text { Random, } 95 \% \mathrm{Cl}\end{array}$} & \multirow{2}{*}{\multicolumn{4}{|c|}{$\begin{array}{c}\text { Odds Ratio } \\
\text { M- } \mathrm{H}, \text { Random, } 95 \% \mathrm{Cl}\end{array}$}} \\
\hline & Events & Total & Events & Total & & & & & & \\
\hline \multicolumn{11}{|c|}{ 28.1.1 Kontrol gruplu çalışma } \\
\hline Becker 2015 & 3 & 14 & 0 & 12 & $1.4 \%$ & $7.61[0.35,163.82]$ & & & & \\
\hline Duval 2015 & 15 & 24 & 12 & 31 & $6.1 \%$ & $2.64[0.88,7.91]$ & & & & \\
\hline Einarsson 2017 & 45 & 152 & 42 & 153 & $10.0 \%$ & $1.11[0.68,1.83]$ & & & $\leftarrow$ & \\
\hline Einarsson 2018 & 45 & 160 & 41 & 157 & $10.0 \%$ & $1.11[0.67,1.82]$ & & & 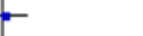 & \\
\hline Espinos 2017 & 11 & 21 & 6 & 20 & $5.2 \%$ & $2.57[0.71,9.27]$ & & & & \\
\hline Goldman 2016 & 29 & 55 & 15 & 19 & $5.5 \%$ & $0.30[0.09,1.01]$ & & & & \\
\hline Grzegorczyk 2020 & 19 & 83 & 10 & 83 & $7.7 \%$ & $2.17[0.94,5.00]$ & & & & \\
\hline Moran 2011 & 7 & 18 & 5 & 20 & $4.8 \%$ & $1.91[0.48,7.64]$ & & $\rightarrow$ & & \\
\hline Mutsaerts 2016 & 123 & 280 & 153 & 284 & $11.0 \%$ & $0.67[0.48,0.93]$ & & $\rightarrow$ & & \\
\hline Oers 2016 & 149 & 280 & 165 & 284 & $11.0 \%$ & $0.82[0.59,1.14]$ & & $\rightarrow$ & & \\
\hline Oers 2017 & 76 & 280 & 100 & 284 & $10.9 \%$ & $0.69[0.48,0.98]$ & & $\rightarrow$ & & \\
\hline Palomba 2014 & 10 & 41 & 13 & 175 & $7.2 \%$ & $4.02[1.62,9.98]$ & & & $\longrightarrow$ & \\
\hline Rothberg 2016 & 3 & 6 & 0 & 5 & $1.3 \%$ & $11.00[0.43,284.30]$ & & & & \\
\hline $\begin{array}{l}\text { Sim } 2014 \\
\text { Subtotal }(95 \% \mathrm{Cl})\end{array}$ & 12 & $\begin{array}{r}27 \\
1441\end{array}$ & 3 & $\begin{array}{r}22 \\
1549\end{array}$ & $\begin{array}{r}4.6 \% \\
96.8 \%\end{array}$ & $\begin{array}{r}5.07[1.21,21.28] \\
1.28[0.90,1.81]\end{array}$ & & & & \\
\hline Total events & 547 & & 565 & & & & & & & \\
\hline \multicolumn{11}{|c|}{$\begin{array}{l}\text { Heterogeneity: } \mathrm{Tau}^{2}=0.22 ; \mathrm{Chi}^{2}=41.52, \mathrm{df}=13(P<0.0001) ;\left.\right|^{2}=69 \% \\
\text { Test for overall effect: } Z=1.38(P=0.17)\end{array}$} \\
\hline \multicolumn{11}{|c|}{ 28.1.2 Öntest sontest kontrollü } \\
\hline Milone 2017 & 14 & 40 & 0 & 40 & $1.6 \%$ & $44.32[2.53,775.00]$ & & & & \\
\hline $\begin{array}{l}\text { Musella } 2011 \\
\text { Subtotal }(95 \% \mathrm{Cl})\end{array}$ & 14 & $\begin{array}{l}23 \\
63\end{array}$ & 0 & $\begin{array}{l}23 \\
63\end{array}$ & $\begin{array}{l}1.6 \% \\
3.2 \%\end{array}$ & $\begin{array}{r}71.74[3.88,1327.65] \\
56.12[7.27,4332.94]\end{array}$ & & & & \\
\hline Total events & 28 & & 0 & & & & & & & \\
\hline \multicolumn{11}{|c|}{$\begin{array}{l}\text { Heterogeneity: } \text { Tau }^{2}=0.00 ; \mathrm{Chi}^{2}=0.05, \mathrm{df}=1(P=0.82) ;\left.\right|^{2}=0 \% \\
\text { Test for overall effect: } Z=3.86(P=0.0001)\end{array}$} \\
\hline Total $(95 \% \mathrm{Cl})$ & & 1504 & & 1612 & $100.0 \%$ & $1.50[1.02,2.22]$ & & & & \\
\hline Total events & 575 & & 565 & & & & & & & \\
\hline $\begin{array}{l}\text { Heterogeneity: Tauz } \\
\text { Test for overall effect } \\
\text { Test for subqroup dif }\end{array}$ & $\begin{array}{l}0.33 ; \mathrm{Chi} \\
\mathrm{Z}=2.05 \\
\text { erences: }\end{array}$ & $\begin{array}{l}\mathrm{i}^{2}=57.6 \\
(\mathrm{P}=0.0 \\
\mathrm{Chi}=1\end{array}$ & $\begin{array}{l}60, d f=1 \\
4) \\
12.80, d f\end{array}$ & $5(P<0$ & $.00001) ;$ & $I^{2}=92.2 \%$ & 0.001 & Müdahale & Kontrol & 1000 \\
\hline
\end{tabular}

Çoğul doğum

\begin{tabular}{|c|c|c|c|c|c|c|c|c|}
\hline \multirow[b]{2}{*}{ Study or Subgroup } & \multicolumn{2}{|c|}{ Müdahale } & \multicolumn{2}{|c|}{ Kontrol } & \multirow[b]{2}{*}{ Weight } & \multirow{2}{*}{$\begin{array}{c}\text { Odds Ratio } \\
\text { M-H, Fixed, } 95 \% \mathrm{Cl}\end{array}$} & \multirow{2}{*}{\multicolumn{2}{|c|}{$\begin{array}{c}\text { Odds Ratio } \\
\text { M-H, Fixed, } 95 \% \mathrm{Cl}\end{array}$}} \\
\hline & Events & Total & Events & Total & & & & \\
\hline Einarsson 2017 & 0 & 66 & 1 & 56 & $4.0 \%$ & $0.28[0.01,6.97]$ & & \\
\hline Grzegorczyk 2020 & 3 & 31 & 0 & 23 & $1.3 \%$ & $5.77[0.28,117.46]$ & & \\
\hline Moran 2011 & 1 & 12 & 0 & 8 & $1.3 \%$ & $2.22[0.08,61.40]$ & & \\
\hline Mutsaerts 2016 & 47 & 175 & 53 & 186 & $93.4 \%$ & $0.92[0.58,1.46]$ & & \\
\hline Total $(95 \% \mathrm{Cl})$ & & 284 & & 273 & $100.0 \%$ & $0.97[0.63,1.51]$ & & \\
\hline Total events & 51 & & 54 & & & & & \\
\hline $\begin{array}{l}\text { Heterogeneity: } \mathrm{Chi}^{2}= \\
\text { Test for overall effect }\end{array}$ & $\begin{array}{l}2.21, d f= \\
Z=0.12\end{array}$ & $\begin{array}{l}3(P= \\
P=0.9\end{array}$ & $\begin{array}{l}0.53) ; 1^{2}= \\
\text { 1) }\end{array}$ & $=0 \%$ & & & 0.005 & $\begin{array}{lll}0.1 & 1 & 10 \\
\text { Müdahale Kontrol }\end{array}$ \\
\hline
\end{tabular}

\section{Sezaryen doğum}

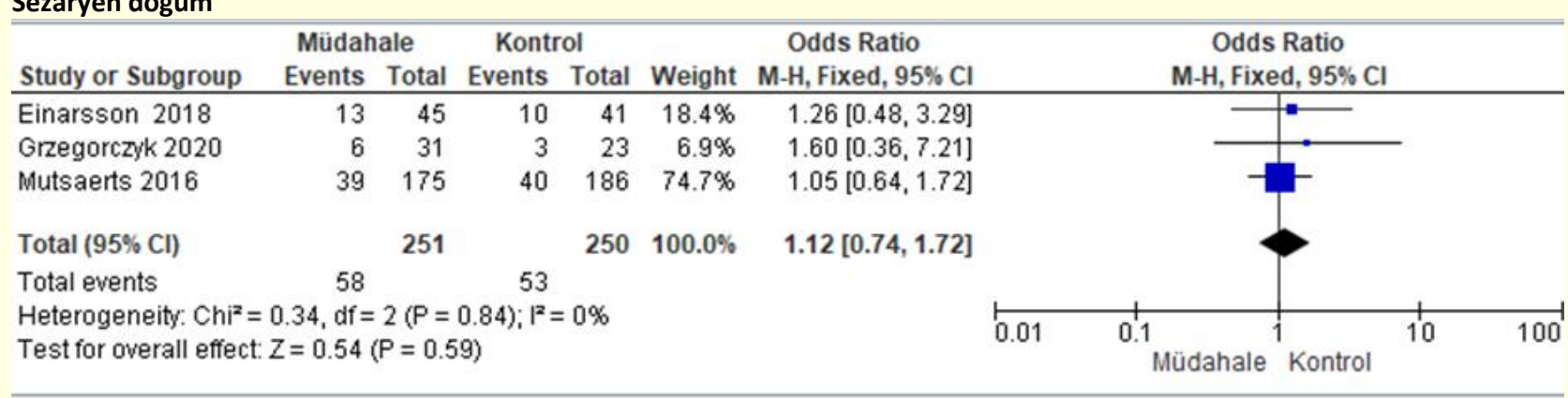




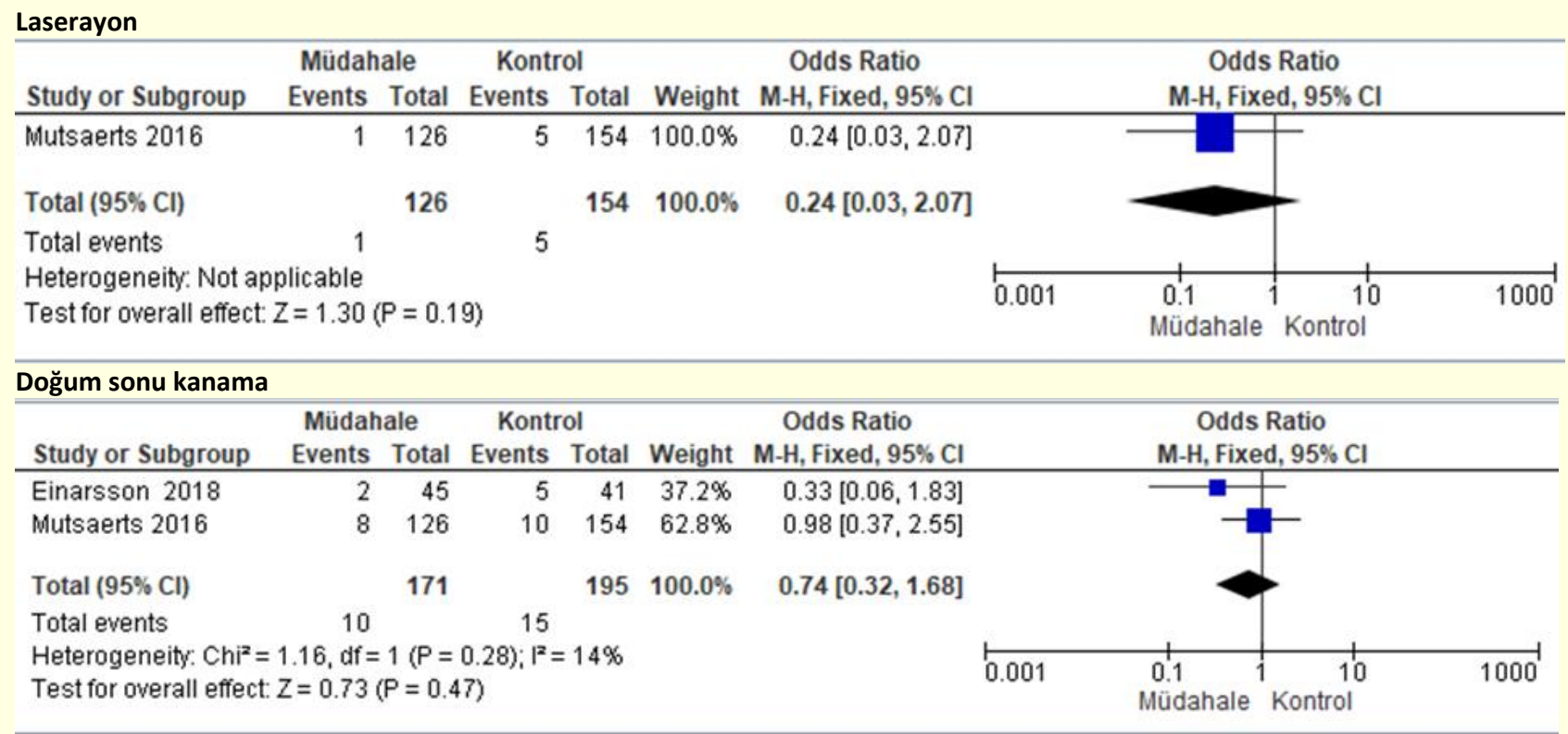

Şekil 4. Müdahale ve Kontrol Gruplarının Doğum İle İlgili Meta-Analiz Bulguları

\section{Obstetrik komplikasyonlar ve kadın sağlığı ile ilgili meta-analiz bulguları}

Bu çalışmada incelenen kontrol gruplu yedi ve ön test-son test kontrollü iki araştırmada obez infertil kadınlarda uygulanan kilo yönetim müdahalelerinin abortus sonuçları üzerine etkisi ile ilgili sonuçlar bulunmakta idi. ${ }^{15,17-19,22,24,26,29,31}$ Yapılan meta-analizde müdahale grubunda abortus oranının istatistiksel olarak anlamlı bir şekilde 1.58 kat daha fazla olduğu bulunmuştur (OR: 1.58, 95\%: $1.11-2.23, \mathrm{Z}=2.57, \mathrm{p}=0.01$, Şekil 5). Bu veri setinde kontrol gruplu çalışmaların meta-analizinde, müdahale grubunda abortus oranının istatistiksel olarak anlamlı bir şekilde 1.55 kat daha fazla olduğunu saptanmıştır (OR: 1.55, 95\%: 1.09 - 2.20, $\mathrm{Z}=2.43, \mathrm{p}=0.01$, Şekil 5). Yine ön test-son test kontrollü çalışmaların birleştirilmiş sonuçlarında da müdahale grubunda abortus görülme olasılığının 3.1 kat daha fazla olduğu, ancak bu sonucun istatistiksel olarak anlamlı olmadığı saptanmıştır (OR: 3.10, 95\%: 0.31 - 30.72, Z=0.97, p=0.33, şekil 5).

Çalışmaya dahil edilen iki araştırmada obez infertil kadınlarda uygulanan müdahalenin ektopik gebelik üzerine etkisi ile ilgili sonuçlar mevcuttu. ${ }^{17,26}$ Bu sonuçlar ile yapılan meta-analizde müdahale ve kontrol gruplarının ektopik gebelik gelişimi bakımından istatistiksel olarak benzer olduğu bulunmuştur (OR: 0.63, 95\%: 0.20 - 1.94, Z=0.81, p=0.42, Şekil 5).

Bu sistematik derleme ve meta-analizde incelenen üç araştırmada obez infertil kadınlarda uygulanan kilo yönetim müdahalelerinin preterm doğum üzerine etkisi ile ilgili sonuçlar bulunmakta idi. ${ }^{16,18,26}$ Bu çalışmaların birleştirilmiş sonuçları, bu müdahalelerin preterm doğum gelişiminde etkili olmadığını göstermiştir (OR: 0.85, 95\%: 0.47 - 1.56, Z=0.51, p=0.61, Şekil 5).

Bu sistematik derleme ve meta-analizde incelenen üç araştırmada obez infertil kadınlarda uygulanan kilo yönetim müdahalelerinin preeklemsi gelişimi üzerine etkisi ile ilgili sonuçlar rapor edilmişti. ${ }^{16,26,31} \mathrm{Bu}$ çalışmaların birleştirilmiş sonuçları, müdahale grubunda preeklemsi gelişiminin azaldığı, ancak bu sonucun istatistiksel olarak anlamlı olmadığını göstermiştir (OR: 0.75, 95\%: $0.38-1.49, \mathrm{Z}=0.82, \mathrm{p}=0.41$, Şekil 5).

Çalışmada incelenen üç araştırmada obez infertil kadınlarda uygulanan kilo yönetim müdahalelerinin gestasyonel diyabet gelişimine etkisi ile ilgili sonuç bildirilmişti. ${ }^{16,26,31}$ Bu çalışmalara dayalı yapılan metaanalizde, müdahale grubunda gestasyonel diyabet görülme olasılığının azaldığı, ancak bu sonucun istatistiksel olarak anlamlı olmadığı saptanmıştır (OR: 0.64, 95\%: 0.37 - 1.11, Z=1.59, p=0.11, şekil 5). 
Bu sistematik derlemede incelenen üç araştırmada obez infertil kadınlarda uygulanan kilo yönetim müdahalelerinin gestasyonel hipertansiyon gelişimi üzerine etkisi ile ilgili sonuçlar bulunmakta idi. ${ }^{16,26,31}$ Yapılan meta-analizde, müdahale grubunda gestasyonel hipertansiyon gelişiminin daha az olduğu, ancak bu sonucun istatistiksel olarak anlamlı olmadığı belirlenmiştir (OR: 0.90, 95\%: $0.52-1.56, Z=0.37, p=0.71$, şekil 5).

Bu sistematik derlemede incelenen bir araştırmada kilo yönetim müdahalesinin HELLP sendromu üzerine etkisi ile ilgili sonuç bildirilmişti. ${ }^{26} \mathrm{Bu}$ çalışmanın bulguları müdahale grubunda HELLP sendromu gelişiminin 1.6 kat daha fazla olduğunu, ancak bu sonucun istatistiksel olarak anlamlı olmadığını göstermiştir (OR: 1.60, 95\%: 0.26 - 9.72, Z=0.51, $p=0.61$, şekil 5).

Abortus

\begin{tabular}{|c|c|c|c|c|c|c|c|c|c|}
\hline \multirow[b]{2}{*}{ Study or Subgroup } & \multicolumn{2}{|c|}{ Müdahale } & \multicolumn{2}{|c|}{ Kontrol } & \multirow[b]{2}{*}{ Weight } & \multirow{2}{*}{$\begin{array}{l}\text { Odds Ratio } \\
\mathrm{M}-\mathrm{H} \text {, Fixed, } 95 \% \mathrm{Cl}\end{array}$} & \multirow{2}{*}{\multicolumn{3}{|c|}{$\begin{array}{l}\text { Odds Ratio } \\
\text { M-H, Fixed, } 95 \% \mathrm{Cl}\end{array}$}} \\
\hline & Events & Total & Events & Total & & & & & \\
\hline \multicolumn{10}{|c|}{ 29.1.1 Kontrol Grubu olan } \\
\hline Einarsson 2017 & 12 & 152 & 8 & 153 & $14.3 \%$ & $1.55[0.62,3.91]$ & & & \\
\hline Espinos 2017 & 1 & 21 & 1 & 20 & $1.9 \%$ & $0.95[0.06,16.29]$ & & & \\
\hline Goldman 2016 & 11 & 55 & 2 & 19 & $4.6 \%$ & $2.13[0.43,10.60]$ & & & \\
\hline Grzegorczyk 2020 & 12 & 83 & 13 & 83 & $21.6 \%$ & $0.91[0.39,2.13]$ & & & \\
\hline Mutsaerts 2016 & 41 & 280 & 27 & 284 & $44.5 \%$ & $1.63[0.97,2.74]$ & & & \\
\hline Palomba 2014 & 6 & 41 & 15 & 175 & $9.5 \%$ & $1.83[0.66,5.05]$ & & & \\
\hline $\begin{array}{l}\text { Sim } 2014 \\
\text { Subtotal }(95 \% \mathrm{Cl})\end{array}$ & 5 & $\begin{array}{r}27 \\
659\end{array}$ & 1 & $\begin{array}{r}22 \\
756\end{array}$ & $\begin{array}{r}1.7 \% \\
98.2 \%\end{array}$ & $\begin{array}{r}4.77[0.51,44.33] \\
1.55[1.09,2.20]\end{array}$ & & & \\
\hline \multicolumn{10}{|c|}{$\begin{array}{l}\text { Heterogeneity: } C h i^{2}=2.88, \mathrm{df}=6(P=0.82) ;\left.\right|^{2}=0 \% \\
\text { Test for overall effect: } Z=2.43(P=0.01)\end{array}$} \\
\hline \multicolumn{10}{|l|}{ 29.1.2 Ön test grubu } \\
\hline Milone 2017 & 1 & 40 & 0 & 40 & $0.9 \%$ & $3.08[0.12,77.80]$ & & & \\
\hline $\begin{array}{l}\text { Musella } 2011 \\
\text { Subtotal }(95 \% \mathrm{Cl})\end{array}$ & 1 & $\begin{array}{l}23 \\
63\end{array}$ & 0 & $\begin{array}{l}23 \\
63\end{array}$ & $\begin{array}{l}0.9 \% \\
1.8 \%\end{array}$ & $\begin{array}{l}3.13[0.12,81.00] \\
3.10[0.31,30.72]\end{array}$ & & & \\
\hline \multicolumn{10}{|c|}{$\begin{array}{l}\text { Heterogeneity: } \mathrm{Chi}^{2}=0.00, \mathrm{df}=1(P=0.99) ;\left.\right|^{2}=0 \% \\
\text { Test for overall effect: } Z=0.97(P=0.33)\end{array}$} \\
\hline Total $(95 \% \mathrm{Cl})$ & & 722 & & 819 & $100.0 \%$ & $1.58[1.11,2.23]$ & & & \\
\hline Total events & 90 & & 67 & & & & & & \\
\hline $\begin{array}{l}\text { Heterogeneity: } \mathrm{Chi}^{2}= \\
\text { Test for overall effect } \\
\text { Test for subqroup dif }\end{array}$ & $\begin{array}{l}3.24, \mathrm{df}= \\
Z=2.57 \\
\text { erences: }\end{array}$ & $\begin{array}{l}8(P= \\
P=0.0 \\
C h i^{2}=0\end{array}$ & $\begin{array}{l}0.92) ; 1^{2}= \\
\text { 1) } \\
0.35, d f=\end{array}$ & $1(P=0$ & $0.56) .1^{2}=0$ & $0 \%$ & 0.01 & 0.1 Müdahale Kontrol & $100^{\circ}$ \\
\hline \multicolumn{10}{|c|}{ Ektopik gebelik } \\
\hline Study or Subgroup & \multicolumn{2}{|c|}{ Müdahale } & Kontrol & ol & Weight & $\begin{array}{l}\text { Odds Ratio } \\
\text { M-H, Fixed, } 95 \% \mathrm{Cl}\end{array}$ & \multicolumn{3}{|c|}{$\begin{array}{c}\text { Odds Ratio } \\
\text { M-H, Fixed, } 95 \% \mathrm{Cl}\end{array}$} \\
\hline $\begin{array}{l}\text { Einarsson } 2017 \\
\text { Mutsaerts } 2016\end{array}$ & $\begin{array}{l}1 \\
4\end{array}$ & $\begin{array}{l}152 \\
280\end{array}$ & $\begin{array}{l}1 \\
7\end{array}$ & $\begin{array}{l}153 \\
284\end{array}$ & $\begin{array}{l}12.6 \% \\
87.4 \%\end{array}$ & $\begin{array}{r}1.01[0.06,16.24] \\
0.57[0.17,1.98]\end{array}$ & & & \\
\hline Total $(95 \% \mathrm{Cl})$ & & 432 & & 437 & $100.0 \%$ & $0.63[0.20,1.94]$ & & & \\
\hline Total events & 5 & & 8 & & & & & & \\
\hline \multicolumn{7}{|c|}{$\begin{array}{l}\text { Heterogeneity: } \mathrm{Chi}^{2}=0.13, \mathrm{df}=1(P=0.72) ;\left.\right|^{2}=0 \% \\
\text { Test for overall effect: } Z=0.81(P=0.42)\end{array}$} & 0.001 & $\begin{array}{cc}0.1 & 1 \\
\text { Müdahale Kontrol }\end{array}$ & 1000 \\
\hline \multicolumn{10}{|l|}{ Preterm doğum } \\
\hline Study or Subgroup & \multicolumn{2}{|c|}{ Müdahale } & \multicolumn{2}{|c|}{ Kontrol } & Weight & $\begin{array}{c}\text { Odds Ratio } \\
\text { M-H, Fixed, } 95 \% \mathrm{Cl}\end{array}$ & \multicolumn{3}{|c|}{$\begin{array}{c}\text { Odds Ratio } \\
\text { M-H, Fixed, } 95 \% \mathrm{Cl}\end{array}$} \\
\hline Einarsson 2018 & 3 & 45 & 1 & 41 & $4.3 \%$ & $2.86[0.29,28.62]$ & & & \\
\hline $\begin{array}{l}\text { Goldman } 2016 \\
\text { Mutsaerts } 2016\end{array}$ & $\begin{array}{r}3 \\
17\end{array}$ & $\begin{array}{r}44 \\
175\end{array}$ & $\begin{array}{r}2 \\
22\end{array}$ & $\begin{array}{r}16 \\
186\end{array}$ & $\begin{array}{l}11.9 \% \\
83.8 \%\end{array}$ & $\begin{array}{l}0.51[0.08,3.39] \\
0.80[0.41,1.57]\end{array}$ & & & \\
\hline Total $(95 \% \mathrm{Cl})$ & & 264 & & 243 & $100.0 \%$ & $0.85[0.47,1.56]$ & & & \\
\hline Total events & 23 & & 25 & & & & & & \\
\hline $\begin{array}{l}\text { Heterogeneity: } \mathrm{Chi}^{2}= \\
\text { Test for overall effect }\end{array}$ & $\begin{array}{l}1.37, \mathrm{df}= \\
Z=0.51\end{array}$ & $\begin{array}{l}=2(P= \\
(P=0 . E\end{array}$ & $\begin{array}{l}0.50) ; 1^{2}= \\
\text { 61) }\end{array}$ & $=0 \%$ & & & 0.005 & $\begin{array}{ll}0.1 & 10 \\
\text { Müdahale Kontrol } & 10\end{array}$ & 200 \\
\hline
\end{tabular}


Preeklemsi

\begin{tabular}{|c|c|c|c|c|c|c|c|c|}
\hline \multirow[b]{2}{*}{ Study or Subgroup } & \multicolumn{2}{|c|}{ Müdahale } & \multicolumn{2}{|c|}{ Kontrol } & \multirow[b]{2}{*}{ Weight } & \multirow{2}{*}{$\begin{array}{c}\text { Odds Ratio } \\
\text { M-H, Fixed, } 95 \% \mathrm{Cl}\end{array}$} & \multirow{2}{*}{$\begin{array}{c}\text { Odds Ratio } \\
\text { M-H, Fixed, } 95 \% \mathrm{Cl}\end{array}$} & \\
\hline & Events & Total & Events & Total & & & & \\
\hline Einarsson 2018 & 5 & 45 & 4 & 41 & $19.5 \%$ & $1.16[0.29,4.64]$ & & \\
\hline Mutsaerts 2016 & 10 & 175 & 16 & 186 & $76.8 \%$ & $0.64[0.28,1.46]$ & & \\
\hline $\operatorname{Sim} 2014$ & 1 & 13 & 0 & 3 & $3.6 \%$ & $0.84[0.03,25.50]$ & & \\
\hline Total $(95 \% \mathrm{Cl})$ & & 233 & & 230 & $100.0 \%$ & $0.75[0.38,1.49]$ & & \\
\hline Total events & 16 & & 20 & & & & & \\
\hline $\begin{array}{l}\text { Heterogeneity: } \mathrm{Chi}^{2} \\
\text { Test for overall effec }\end{array}$ & $\begin{array}{l}0.51, d f= \\
Z=0.82(\end{array}$ & $\begin{array}{l}2(P= \\
P=0.4\end{array}$ & $\begin{array}{l}0.77) ; 1^{2}= \\
1)\end{array}$ & $=0 \%$ & & & $\begin{array}{ll}0.1 & 1 \\
\text { Müdahale } & 10 \\
\text { Kontrol }\end{array}$ & 500 \\
\hline
\end{tabular}

\section{Gestasyonel diyabet}

\begin{tabular}{|c|c|c|c|c|c|c|c|}
\hline \multirow[b]{2}{*}{ Study or Subgroup } & \multicolumn{2}{|c|}{ Müdahale } & \multicolumn{2}{|c|}{ Kontrol } & \multirow[b]{2}{*}{ Weight } & \multirow{2}{*}{$\begin{array}{c}\text { Odds Ratio } \\
\text { M-H, Fixed, } 95 \% \mathrm{Cl}\end{array}$} & \multirow{2}{*}{$\begin{array}{c}\text { Odds Ratio } \\
\text { M-H, Fixed, } 95 \% \mathrm{Cl}\end{array}$} \\
\hline & Events & Total & Events & Total & & & \\
\hline Einarsson 2018 & 1 & 45 & 2 & 41 & $6.4 \%$ & $0.44[0.04,5.08]$ & \\
\hline Mutsaerts 2016 & 23 & 175 & 33 & 186 & $86.6 \%$ & $0.70[0.39,1.25]$ & \\
\hline $\operatorname{Sim} 2014$ & 0 & 13 & 1 & 3 & $7.0 \%$ & $0.06[0.00,1.99]$ & \\
\hline Total $(95 \% \mathrm{Cl})$ & & 233 & & 230 & $100.0 \%$ & $0.64[0.37,1.11]$ & \\
\hline Total events & 24 & & 36 & & & & \\
\hline $\begin{array}{l}\text { Heterogeneity: } \mathrm{Chi}^{2}= \\
\text { Test for overall effect }\end{array}$ & $\begin{array}{l}.93, \mathrm{df}= \\
=1.590\end{array}$ & $\begin{array}{l}2(P= \\
P=0.1\end{array}$ & $\begin{array}{l}0.38) ; 1^{2}= \\
\text { 1) }\end{array}$ & $0 \%$ & & & $\begin{array}{cc}0.1 & 1 \\
\text { Müdahale } & 10 \\
\text { Kontrol }\end{array}$ \\
\hline
\end{tabular}

\begin{tabular}{|c|c|c|c|c|c|c|c|c|c|}
\hline \multicolumn{10}{|c|}{ Gestasyonel hipertansiyon } \\
\hline \multirow[b]{2}{*}{ Study or Subgroup } & \multicolumn{2}{|c|}{ Müdahale } & \multicolumn{2}{|c|}{ Kontrol } & \multirow[b]{2}{*}{ Weight } & \multicolumn{2}{|l|}{ Odds Ratio } & \multirow{2}{*}{$\begin{array}{c}\text { Odds Ratio } \\
\text { M-H, Fixed, } 95 \% \mathrm{Cl}\end{array}$} & \\
\hline & Events & Total & Events & Total & & M-H, Fixed, 95\% Cl & & & \\
\hline Einarsson 2018 & 1 & 45 & 2 & 41 & $7.7 \%$ & $0.44[0.04,5.08]$ & & & \\
\hline Mutsaerts 2016 & 26 & 175 & 27 & 186 & $83.8 \%$ & $1.03[0.57,1.84]$ & & & \\
\hline $\operatorname{Sim} 2014$ & 0 & 13 & 1 & 3 & $8.5 \%$ & $0.06[0.00,1.99]$ & & & \\
\hline Total $(95 \% \mathrm{Cl})$ & & 233 & & 230 & $100.0 \%$ & $0.90[0.52,1.56]$ & & & \\
\hline Total events & 27 & & 30 & & & & & & \\
\hline $\begin{array}{l}\text { Heterogeneity: } \mathrm{Chi}^{2} \\
\text { Test for overall effec }\end{array}$ & $\begin{array}{l}2.81, d f= \\
Z=0.37\end{array}$ & $\begin{array}{l}2(P= \\
P=0.7\end{array}$ & $\begin{array}{l}0.25) ; 1^{2}= \\
\text { 1) }\end{array}$ & $=29 \%$ & & & 0.002 & $\begin{array}{cc}0.1 & 1 \\
\text { Müdahale Kontrol }\end{array}$ & 500 \\
\hline \multicolumn{10}{|l|}{ HELLP Sendromu } \\
\hline \multirow[b]{2}{*}{ Study or Subgroup } & \multicolumn{2}{|c|}{ Müdahale } & \multicolumn{2}{|c|}{ Kontrol } & \multicolumn{2}{|c|}{ Odds Ratio } & \multirow{2}{*}{\multicolumn{3}{|c|}{$\begin{array}{c}\text { Odds Ratio } \\
\text { M-H, Fixed, } 95 \% \mathrm{Cl}\end{array}$}} \\
\hline & Events & Total & Events & Total & Weight & M-H, Fixed, $95 \% \mathrm{Cl}$ & & & \\
\hline Mutsaerts 2016 & 3 & 175 & 2 & 186 & $100.0 \%$ & $1.60[0.26,9.72]$ & & & \\
\hline Total $(95 \% \mathrm{Cl})$ & & 175 & & 186 & $100.0 \%$ & $1.60[0.26,9.72]$ & & & \\
\hline Total events & 3 & & 2 & & & & & & \\
\hline \multicolumn{7}{|c|}{$\begin{array}{l}\text { Heterogeneity: Not applicable } \\
\text { Test for overall effect: } Z=0.51(P=0.61)\end{array}$} & 0.002 & $\begin{array}{cc}0.1 & 1 \\
\text { Müdahale } & 10 \\
\end{array}$ & 500 \\
\hline
\end{tabular}

Şekil 5. Müdahale ve Kontrol Gruplarının Obstetrik Komplikasyonlar ve Kadın Sağlı̆ıı Ile Illgili Meta-Analiz Bulguları

\section{Yenidoğan ile ilgili meta-analiz bulguları}

Bu sistematik derlemeye dahil edilen iki araştırmada obez infertil kadınlarda uygulanan müdahalenin doğum sonrası 5. dakika APGAR<7 olması üzerine etkisi ile ilgili sonuç bildirilmişti. ${ }^{16,26} \mathrm{Bu}$ çalışma bulgularına dayalı yapılan meta-analizde müdahale grubunda 5. dakika APGAR<7 görülme olasılığının daha az olduğu, ancak bu sonucun istatistiksel olarak anlamlı olmadığı saptanmıştır (OR: 0.62, 95\%: $0.17-2.31, Z=0.71, p=0.48$, şekil 6).

Çalışmada incelenen iki araştırmada obez infertil kadınlarda uygulanan kilo yönetim müdahalelerinin konjenital anomali üzerine etkileri ile ilgili sonuç rapor edilmişti. ${ }^{16,26}$ Bu çalışmaların meta-analiz sonuçları, müdahale ve kontrol gruplarının konjenital anomali görülme sıklığı bakımından istatistiksel olarak benzer olduğunu göstermiştir (OR: 1.11, 95\%: 0.38 - 3.24, Z=0.18, p=0.85, Şekil 6).

Çalışmada incelenen bir araştırmada obez infertil kadınlarda uygulanan kilo yönetim müdahalesinin perinatal mortalite, düşük doğum ağırlığı, iri bebek ve omuz distosisi, yenidoğan yoğun bakıma yatışına ilişkin sonuçlar 
mevcuttu. ${ }^{26}$ Bu çalışmanın sonuçları müdahale ve kontrol gruplarının bu değişkenler bakımından benzer olduğunu göstermiştir (Şekil 6).

$\mathrm{Bu}$ sistematik derlemede incelenen üç araştırmada obez infertil kadınlarda uygulanan kilo yönetim müdahalelerinin doğum ağırlığı üzerine etkisi ile ilgili sonuçlar bulunmakta idi. ${ }^{16,18,19}$ Bu çalışmalara dayalı yapılan meta-analizde, müdahale grubundaki kadınların bebeklerinin doğum ağırlığı ortalamasının istatistiksel olarak anlamlı bir şeklide kontrol grubundakilere göre daha az olduğu saptanmıştır (SMD: -0.77, 95\%:-1.49 - -0.05, Z=2.10, $p=0.04$, Şekil 6).

\section{5. dakika APGAR<7}

\begin{tabular}{|c|c|c|c|c|c|c|c|c|c|}
\hline \multirow[b]{2}{*}{ Study or Subgroup } & \multicolumn{2}{|c|}{ Müdahale } & \multicolumn{2}{|c|}{ Kontrol } & \multirow[b]{2}{*}{ Weight } & \multirow{2}{*}{$\begin{array}{c}\text { Odds Ratio } \\
\text { M-H, Fixed, } 95 \% \mathrm{Cl}\end{array}$} & \multirow{2}{*}{\multicolumn{2}{|c|}{$\begin{array}{c}\text { Odds Ratio } \\
\text { M-H, Fixed, } 95 \% \mathrm{Cl}\end{array}$}} & \\
\hline & Events & Total & Events & Total & & & & & \\
\hline Einarsson 2018 & 0 & 45 & 1 & 41 & $26.3 \%$ & $0.30[0.01,7.49]$ & & & \\
\hline Mutsaerts 2016 & 3 & 123 & 5 & 153 & $73.7 \%$ & $0.74[0.17,3.16]$ & & & \\
\hline Total $(95 \% \mathrm{Cl})$ & & 168 & & 194 & $100.0 \%$ & $0.62[0.17,2.31]$ & & & \\
\hline Total events & 3 & & 6 & & & & & & \\
\hline $\begin{array}{l}\text { Heterogeneity: } \mathrm{Chi}^{2} \\
\text { Test for overall effec }\end{array}$ & $\begin{array}{l}0.26, \mathrm{df}= \\
Z=0.71\end{array}$ & $\begin{array}{l}1(P= \\
P=0.4\end{array}$ & $\begin{array}{l}0.61) ;\left.\right|^{2}= \\
8)\end{array}$ & $=0 \%$ & & & 0.001 & $\begin{array}{ccc}0.1 & 1 & 10 \\
\text { Müdahale } & \text { Kontrol }\end{array}$ & 1000 \\
\hline
\end{tabular}

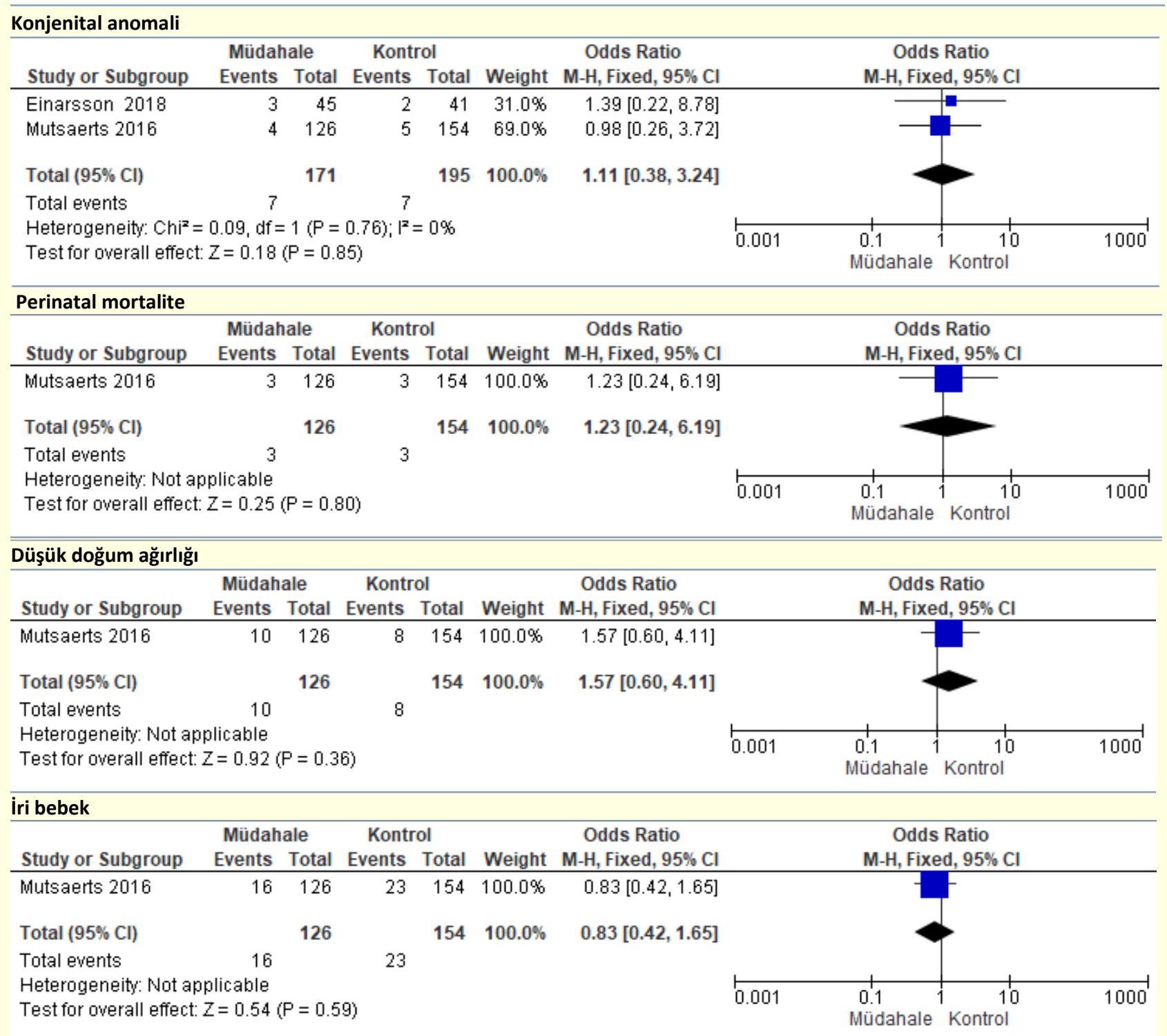


Omuz distosisi

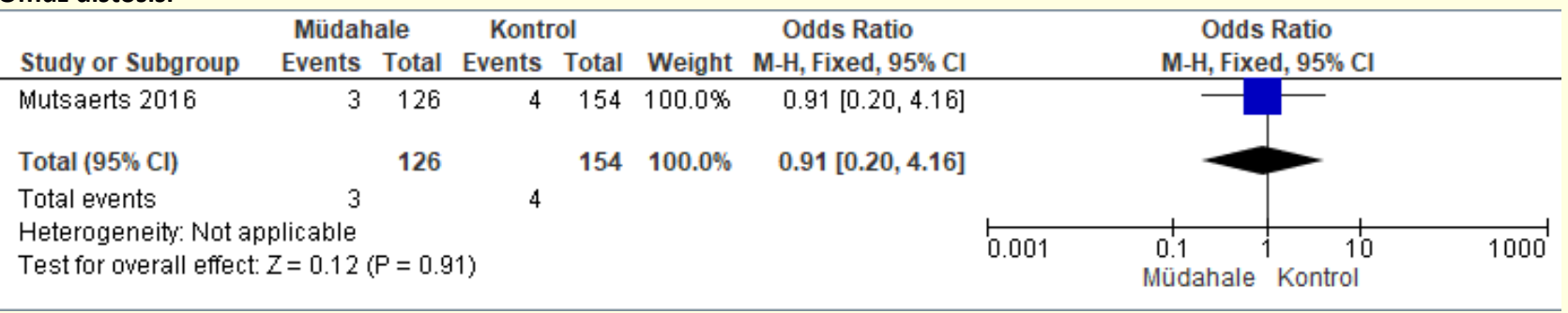

\section{YDYÜ yatış}

\begin{tabular}{|c|c|c|c|c|c|c|c|c|c|}
\hline \multirow[b]{2}{*}{ Study or Subgroup } & \multicolumn{2}{|c|}{ Müdahale } & \multicolumn{2}{|c|}{ Kontrol } & \multirow[b]{2}{*}{ Weight } & \multirow{2}{*}{$\begin{array}{c}\text { Odds Ratio } \\
\text { M-H, Fixed, } 95 \% \mathrm{Cl}\end{array}$} & \multirow{2}{*}{\multicolumn{2}{|c|}{$\begin{array}{c}\text { Odds Ratio } \\
\text { M-H, Fixed, } 95 \% \mathrm{Cl}\end{array}$}} & \\
\hline & Events & Total & Events & Total & & & & & \\
\hline Mutsaerts 2016 & 17 & 126 & 16 & 154 & $100.0 \%$ & $1.35[0.65,2.78]$ & & & \\
\hline Total $(95 \% \mathrm{Cl})$ & & 126 & & 154 & $100.0 \%$ & $1.35[0.65,2.78]$ & & & \\
\hline Total events & 17 & & 16 & & & & & & \\
\hline $\begin{array}{l}\text { Heterogeneity: Not a } \\
\text { Test for overall effect }\end{array}$ & $\begin{array}{l}\text { licable } \\
z=0.80\end{array}$ & $P=0.4$ & & & & & 0.001 & $\begin{array}{ccc}0.1 & 1 & 10 \\
\text { Müdahale Kontrol }\end{array}$ & 1000 \\
\hline
\end{tabular}

\begin{tabular}{|c|c|c|c|c|c|c|c|c|c|c|}
\hline \multicolumn{11}{|l|}{ Doğum ağırlığı } \\
\hline \multirow[b]{2}{*}{ Study or Subgroup } & \multicolumn{3}{|c|}{ Müdahale } & \multicolumn{3}{|c|}{ Kontrol } & \multicolumn{2}{|c|}{ Std. Mean Difference } & \multirow{2}{*}{\multicolumn{2}{|c|}{$\begin{array}{l}\text { Std. Mean Difference } \\
\text { IV, Random, } 95 \% \mathrm{Cl}\end{array}$}} \\
\hline & Mean & SD & Total & Mean & SD & Total & Weight & IV, Random, $95 \% \mathrm{Cl}$ & & \\
\hline Einarsson 2018 & 3,486 & 523 & 45 & 3,584 & 509 & 41 & $39.2 \%$ & $-0.19[-0.61,0.24]$ & - & \\
\hline Goldman 2016 & 2,983 & 510.01 & 29 & 3,583 & 518.93 & 15 & $32.5 \%$ & $-1.15[-1.82,-0.48]$ & $\rightarrow-$ & \\
\hline Grzegorczyk 2020 & 2,753 & 734 & 19 & 3,482 & 263 & 10 & $28.3 \%$ & $-1.15[-1.97,-0.32]$ & - & \\
\hline \multirow{2}{*}{\multicolumn{7}{|c|}{$\begin{array}{l}\text { Heterogeneity: } \text { Tau }^{2}=0.30 ; \mathrm{Chi}^{2}=7.82, \mathrm{df}=2(\mathrm{P}=0.02) ; \mathrm{I}^{2}=74 \% \\
\text { Test for overall effect: } Z=2.10(\mathrm{P}=0.04)\end{array}$}} & $100.0 \%$ & $-0.77[-1.49,-0.05]$ & & \\
\hline & & & & & & & & & $\begin{array}{cccc} & 1 & 1 & 1 \\
-4 & -2 & 0 & 2 \\
& \text { Müdahale } & \text { Kontrol }\end{array}$ & 4 \\
\hline
\end{tabular}

Şekil 6. Müdahale ve Kontrol Gruplarının Yenidoğan İle İlgili Meta-Analiz Bulguları

\section{Fertilizasyon ve obstetrik maliyet ile ilgili meta-analiz bulguları}

Bu sistematik derlemede bir araştırmada obez infertil kadınlara uygulanan kilo yönetim müdahalesinin obstetrik süreçteki maliyet üzerine etkisi ile ilgili sonuç bildirilmişti. ${ }^{28}$ Bu çalışmada müdahale grubundaki ortalama maliyetin istatistiksel olarak anlamlı bir şekilde daha az olduğu saptanmıştır (MD: -1.279.00 dolar, 95\%: -2014.57--543, Z=3.41, p=0.0007, şekil 7).

Obstetrik maliyet

\begin{tabular}{|c|c|c|c|c|c|c|c|c|c|c|c|c|c|c|}
\hline \multirow[b]{2}{*}{ Study or Subgroup } & \multicolumn{3}{|c|}{ Müdahale } & \multicolumn{3}{|c|}{ Kontrol } & \multicolumn{3}{|c|}{ Mean Difference } & \multirow{2}{*}{\multicolumn{4}{|c|}{$\begin{array}{l}\text { Mean Difference } \\
\text { IV, Fixed, } 95 \% \mathrm{Cl}\end{array}$}} & \\
\hline & Mean & SD & Total & Mean & SD & Total & Weight & IV, Fixed, $95 \% \mathrm{Cl}$ & & & & & & \\
\hline Oers 2017 & 4,324 & 4,276 & 280 & 5,603 & 4,632 & 284 & $100.0 \%$ & $-1279.00[-2014.57,-543.43]$ & $\longleftarrow$ & & & & & \\
\hline Total $(95 \%$ Cl) & & & 280 & & & 284 & $100.0 \%$ & $-1279.00[-2014.57,-543.43]$ & & & & & & \\
\hline $\begin{array}{l}\text { Heterogeneity: Not a } \\
\text { Test for overall effec }\end{array}$ & $\begin{array}{l}\text { plicable } \\
Z=3.41\end{array}$ & $(P=0$. & $0007)$ & & & & & & -1000 & $\begin{array}{r}-500 \\
M\end{array}$ & üdahale & Kontrol & 500 & 1000 \\
\hline
\end{tabular}

Şekil 7. Müdahale ve Kontrol Gruplarının Obstetrik Maliyet Ile Illgili Meta-Analiz Bulguları

\section{Tartışma}

Infertil obez kadınlarda obezitenin yönetiminde kullanılan yöntemlerin obstetrik sonuçlara etkinliğinin belirlemesi amacı ile yapılan bu sistematik derleme ve meta-analizde 19 araştırmanın birleştirilmiş sonuçları sunulmuştur. Çalışmada bu kadınlarda obezitenin yönetiminde diyet, egzersiz, eğitim, bireyselleştirilmiş yaşam tarzı değişikliği ve beriatrik cerrahi yöntemlerinin kullanıldığı görülmüştür. Çalışmalarda bu müdahalelerin BKi, gebelik, doğum, obstetrik maliyet, kadın ve bebek sağlığı üzerine etkileri rapor edilmiştir. Bu sonuçlar, infertil obez kadınlarda obezite yönetiminin üreme ve anne-bebek sağlığını geliştirmede yararlanılabilir önemli kanıta dayalı bilgiler olması bakımından değerlidir. 
Bu çalışmada obez infertil kadınlarda obezitenin yönetiminde kullanılan yöntemlerin BKi değişimi üzerine etkili olduğu saptanmıştır. Bu sonuçlar daha önce yapılan çalışmalar ile benzerlik göstermektedir. ${ }^{14}$ Ayrıca kadınların, gebelik öncesi ve gebelik döneminde bebeklerinin sağlığını koruyacağına inandıkları için, kilo yönetimi gibi sağlıklı yaşam tarzı geliştirmeye motive oldukları bildirlmektedir. ${ }^{32}$ Bu bağlamda, gebe kalmayı planlayan obez kadınların izlemi sırasında kilo yönetim danışmanlığı yapılmasının etkili olacağı düşünülmektedir.

Bu çalışmada literatür ile benzer bir şekilde, obez infertil kadınlara uygulanan kilo yönetim müdahalelerinin gebelik oluşumunu etkili bir şekilde arttırdığı bulunmuştur. ${ }^{33}$ Bu sonuçlar sağlık çalışanlarına, gebe kalmayı planlayan aşırı kilolu kadınlara prekonsepsiyonel danışmanlık sürecinde kilo verme danışmanlığının da yapılmasının önemli olduğunu göstermektedir.

Bu meta-analizde, obez infertil kadınlara uygulanan müdahale sonrasında spontan ve yardımlı gebelik oluşumunun arttığı, ancak bu etkinin spontan gebelik bakımından istatistiksel olarak anlamlı olduğu saptanmıştır. Bu bulgulardan farklı olarak, yapılan güncel çalışma ise, kilo verme müdahalesinin spontan veya yardımlı gebelik oluşumunda etkili olmadığı bildirilmiştir. ${ }^{14}$ Diğer yandan spontan gebeliklerin anne-bebek sağlığı sonuçlarının yardımlı gebeliklere göre daha iyi olduğu rapor edilmektedir. ${ }^{34}$ Bu sonuçlara dayalı olarak göre konuya ilişkin daha fazla çalışma yapılması gerektiği söylenebilir.

Bu meta-analizde, obezite müdahale yöntemlerinin çoğul gebelik gelişimi ve dolayısı ile çoğul doğumu etkilemediği saptanmıştır. Bu sonuç, obezite müdahale yöntemlerinin gebelik oluşunu artırırken, çoğul gebelik gibi yüksek riskli bir durumu geliştirmediğini göstermesi bakımından değerlidir.

Bu çalışmada obez infertil kadınlara uygulanan kilo yönetim müdahalelerinin canlı doğum oranını arttırdığı bulunmuştur. Yapılan çalışmalarda da çalışmamızla benzer sonuçlar bildirilmiştir. ${ }^{32,35} \mathrm{Bu}$ sonuç, kilo verme müdahalesinin infertilitenin yönetimine ilave olarak, gebeliğin istendik biçimde sonuçlanmasında da etkili olduğunu göstermektedir.

Bu meta-analizde obez infertil kadınlara uygulanan kilo yönetim müdahalelerinin sezaryen doğum oranı üzerinde etkili olmadığı bulunmuştur. Yapılan bir diğer meta-analizde de benzer sonuçlar bildirilmiştir. ${ }^{36}$ Çalışmamızın aksine literatürde kilo verme müdahalesi sonrası sezaryen olasılığının azaldığı rapor edilmektedir. ${ }^{35,37}$ Bu sonuçlar sezaryen oranı üzerinde obezite ve infertilite dışında farklı değişkenlerin etkili olabileceğini düşündürmektedir.

Bu çalışmada müdahale grubunda laserasyon gelişme olasılığının daha az olduğu, ancak bu sonucun istatistiksel olarak anlamlı olmadığı saptanmıştır. Benzer şekilde Price de gebelik öncesi verilen kilonun, doğum sonu perineal laserasyonu azalttığını bildirmiştir. ${ }^{35}$ Bu sonuçlar kilo yönetiminin perineal laserasyon ve dolayısı ile laserasyon bağlı gelişebilecek olumsuz sonuçların azaltılmasında önemli olduğunu göstermektedir.

Bu meta-analiz sonuçları, müdahale grubunda doğum sonu kanama gelişiminin daha az olduğunu, fakat bu sonucun istatistiksel olarak anlamsız olduğunu göstermiştir. Yapılan iki ayrı meta-analizde de çalışmamızla benzer sonuçlar bildirilmiştir. ${ }^{36,37}$ Öte yandan maternal obezitenin, doğum sonu kanamadaki küresel artışın ana itici güçlerinden biri olduğu düşünülmektedir. ${ }^{33} \mathrm{Bu}$ sonuç, gebelik öncesi obezite yönetim müdahalelerinin doğum sonrası kanama ve dolayısı ile anne ölümlerini azaltmada da etkili olabileceğini göstermektedir.

Bu çalışmada, müdahale grubunda abortus oranlarının istatistiksel olarak anlamlı bir şekilde daha fazla olduğu belirlenmiştir. Benzer şekilde daha önce yapılan meta-analizlerde de müdahale grubunda abortus oranının yüksek olduğu bulunmuştur. ${ }^{14,38}$ Maternal obezitenin abortus oranını arttırdığı bilgisi dikkate alındığında, bu 
çalışmalarda kilo verme müdahalesi sonrası abortus oranındaki artışın, gebelik oranındaki artış ile ilişkili olduğu düşünülmektedir. ${ }^{10}$

Bu çalışmada müdahalelerin ektopik gebelik ve preterm doğum gelişimi üzerinde etkili olmadığını göstermiştir. Bu bilgiden farkıı olarak, literatürde infertil obez kadınlarda kilo yönetim müdahaleleri sonrası preterm doğum oranında azalma olduğu bildirilmektedir. ${ }^{35,37} \mathrm{Bu}$ sonuç, analize alınan çalışmalardaki örneklem grubunda preterm doğuma neden olabilecek obezite dışında endikasyonların olabileceğini, daha homojen gruplar ile ilave çalışmaların yapılması gerektiğini düşündürmektedir.

Çalışmaların birleştirilmiş sonuçları, müdahale grubunda preeklemsi gelişiminin azaldığı, ancak bu sonucun istatistiksel olarak anlamlı olmadığını göstermiştir. Benzer şekilde Price'nin çalışmasında da kilo verme müdahalesinin preeklemsi gelişme olasılı̆̆ını azalttığını bildirmiştir. ${ }^{35}$ Yine daha önce yapılan meta-analizlerde de benzer sonuçlar bildirilmiştir. ${ }^{37}$ Bu sonuçlar gebelik öncesi kilo vermenin preeklemsi ve preeklemsiye bağı komplikasyonları azaltabileceğini göstermesi bakımından önemlidir.

Bu meta-analizde, müdahale grubunda gestasyonel diyabet görülme olasılığının azaldığı, ancak bu sonucun istatistiksel olarak anlamlı olmadığı saptanmıştır. Literatürde de benzer şekilde, müdahale sonrası gestasyonel diyabetin azaldığını bildiren çalışmalar bulunmaktadır. ${ }^{35-37} \mathrm{Bu}$ sonuçlar gebelik öncesi kilo vermenin, gestasyonel diyabete bağlı gelişebilecek komplikasyonların önlenmesi bakımından önemli olduğunu göstermesi bakımından önemlidir.

Bu çalışmada, müdahale grubunda gestasyonel hipertansiyon gelişiminin daha az olduğu, ancak sonucun istatistiksel olarak anlamlı olmadığı belirlenmiştir. Yapılan çalışmalarda da benzer şekilde, gebelik öncesi kilo verme müdahalesinin gestasyonel hipertansiyon oranını azalttığı rapor edilmiştir. ${ }^{35-37} \mathrm{Bu}$ sonuçlar obez infertil kadınlarda vücut kitle indeksindeki gebelik öncesi bir azalmanın gestasyonel hipertansiyonda bir azalmaya yol açabileceğini göstermesi bakımından değerlidir.

Bu çalışmanın bulguları müdahale grubunda HELLP sendromu gelişiminin 1.6 kat daha fazla olduğunu, ancak bu sonucun istatistiksel olarak anlamlı olmadığını göstermiştir. Lisonkova ve ark. da obezitenin HELLP sendromu için risk faktörü olduğunu bildirmişlerdir. ${ }^{39}$ Bu sonuçların yetersiz örneklem hacmine dayalı olması nedeni ile daha geniş kapsamlı çalışmalara gereksinim olduğu düşünülmektedir.

Bu meta-analizde müdahale grubunda 5. dakika APGAR<7 görülme olasılığının daha az olduğu, ancak bu sonucun istatistiksel olarak anlamlı olmadığı saptanmıştır. Daha önce yapılan bir sistematik derleme ve metaanalizde ise maternal obezitenin 5. dakika APGAR<7 skoru ile ilişkili olduğu gösterilmiştir. ${ }^{40}$ Bu sonuçlar, gebelik öncesi kilo verme müdahalesinin yenidoğan sağlığını etkileyebileceğini gösterebilir.

Bu meta-analiz sonuçları, müdahale ve kontrol gruplarının konjenital anomali görülme sıklığı bakımından istatistiksel olarak benzer olduğunu göstermiştir. Yapılan çalışmalarda da benzer sonuçlar rapor edilmiştir. ${ }^{37}$

Bu çalışmanın sonuçları müdahale ve kontrol gruplarının perinatal mortalite, düşük doğum ağırlığı, iri bebek, omuz distosisi ve yenidoğan yoğun bakım ünitesine yatış bakımlarından benzer olduğunu göstermiştir. Benzer şekilde yapılan meta-analizlerde de müdahale ve kontrol grupları arasında iri bebek, YYBÜ (Yenidoğan Yoğun Bakım Ünitesi)'ne yatış ve perinatal mortalite bakımlarından fark olmadığı rapor edilmiştir. ${ }^{35}$ Bu bilgilerin aksine, yapılan diğer çalışmalarda da obez kadınlara yapılan kilo yönetimi müdahalesi sonrası YDYB yatışta, düşük doğum ağırlığı, iri bebek ve omuz distosisini görülme sıklığında azalma olduğu bildirilmiştir. ${ }^{35,37} \mathrm{Bu}$ sonuçlar obez infertil kadınlarda gebelik öncesi dönemdeki kilo kontrolünün yenidoğan komplikasyonlarının azaltılmasında etkili olabileceğini göstermesi bakımından önemlidir.

Bu çalışmada müdahale grubundaki ortalama obstetrik maliyetin istatistiksel olarak anlamlı bir şekilde daha az olduğu saptanmıştır. Literatürde de obez gebelikte maliyetin arttığını bildiren çalışmalar bulunmaktadır. ${ }^{35}$ 
Bu sonuçlar gebelik öncesi kilo kontrolünün aile ve ülke ekonomisine katkı sağlayacağını, bu alanda yapılabilecek harcama kaynaklarının gebelik öncesi kilo verme müdahaleleri için kullanılmasının daha yararlı olabileceği söylenebilir.

\section{Çalışmanın Güçlü Yönleri ve Sınırlıkları}

Bu sistematik derleme ve meta-analizin güçlü yönleri, geniş ilave tarama kaynaklarının bulunması, incelenen araştırmaların çoğunun güncel, farklı ülkelerde yapılmış ve kalite değerlendirme puanlarının daha çok orta ve iyi düzeyde olmasıdır. Ayrıca analize dahil edilen bulguların somut ve ölçülebilir yöntemler ile belirlenmiş olması da bu çalışmanın güçlü yönünün oluşturmuştur. Diğer yandan çalışmaya sadece İngilizce olarak yayınlanan araştırmaların alınması ve diğer dillerde yayınlanan çalışmaların dâhil edilememesi sınırlııı oluşturmuştur. Yine bazı sonuçlar için meta-analizlerin az sayıda ve küçük örneklem hacimli çalışmalara dayalı olması ve çalışmalar arasındaki homojenitenin yüksek olması da elde edilen sonuçların gücünü zayıflatabilir sınırlılık oluşturmuştur.

\section{Sonuç ve Öneriler}

Bu çalışma, obez kadınlarda infertilitenin yönetiminde diyet, egzersiz, eğitim bireyselleştirilmiş yaşam tarzı değişikliği ve beriatrik cerrahi yöntemlerinin kullanıldığı saptanmıştır. Yine çalışmada bu yöntemlerin, kilo verilmesini sağladığı, gebelik oluşumu ve canlı doğum oranını arttırdığı, obstetrik komplikasyonlar, kadın ve bebek sağlığı ile ilgili sonuçları etkilemediği, ancak oluşabilecek riskleri azalttığı, müdahalenin kadında obstetrik maliyetin düştüğü ve abortus oranını arttırdığı sonuçlarını açığa çıkarmıştır. Bu sonuçlar doğrultusunda;

Sağlık hizmeti sunucularının, gebelik planlayan aşırı kilolu kadınlara yönelik planladıkları izlem ve bakım hizmetlerine kilo verme danışmanlığını da entegre etmeleri,

Anne-bebek sağlığının iyileştirilmesi ve maliyet etkinliğin artırılması bakımlarından, bu hizmetin etkinliğinin artırılması ve yaygınlaştırılması için etkili sağlık politikaların hazırlanması ve uygulanması ve

Obez infertil kadınlarda kilo yönetimi ile ilgili kapsamlı bilgiler ortaya koyabilecek ve hizmet kalitesini artırabilecek daha fazla niceliksek ve niteliksel araştırmaların planlanması önerilebilir.

\section{Bilgi}

Yazarlar çıkar çatışması olmadığını açıklamışlardır. Bu çalışma için herhangi bir finansal destek alınmamıştır.

\section{Araştırmacı Katkı Oranı Beyanı}

Döndü Kurnaz: Fikir, tasarım, kaynaklar, analiz ve yorum, kaynak taraması, makale yazımı.

Zekiye Karaçam: Fikir, tasarım, denetleme, kaynaklar, analiz ve yorum, kaynak taraması, makale yazımı, eleştirel inceleme.

\section{Kaynaklar}

1. WHO [Internet]. Obesity and overweight. (2020). [cited by 01.01.2021] Available from: https://www.who.int/news-room/factsh ee ts / de ta il /obesity-and-overweight.

2. Türkiye Nüfus ve Sağlık Araştırması, "Çocukların ve Kadınların Beslenme Durumu", TNSA, Ankara, 2018,159-68.

3. WHO[Internet]. Infertility. (2020). [cited by 01.01.2021] Available from: https://www.who.int/news-room/factsheets/detail/infertility.

4. Küçükdurmaz F, Taşkıran M. Infertil kadınlarda cinsel fonksiyonlar (tanı ve tedavi aşamalarında). Türkiye Klinikleri J Urology 2015;8(3):52-7.

5. Cara DD, Kominiarek MA. Pregnancy in women with obesity. Obstetrics and Gynecology Clinics of North America 2018;45(2):21732. 
6. CDC [Internet]. Infertility and Public Health. Reproductive Health. (2020). [cited by 01.01.2021] Available from: https://www.cdc.gov/reproductivehealth/infertility/publ ichealth.htm.

7. Khaskheli MN, Baloch S, Baloch AS. Infertility and weight reduction: Influence and Outcome. JCPSP 2013;23 (11):798-801.

8. Best $D$, Avenell A, Bhattacharya S. How effective are weight-loss interventions for improving fertility in women and men who are overweight or obese? A systematic review and meta-analysis of the evidence. Hum Reprod Update 2017;23(6):681-705.

9. Seneviratne NS, et al. Antenatal exercise in overweight and obese women and its effects on offspring and maternal health: Design and rationale of the IM. BMC Pregnancy and Childbirth 2014;14:148-156.

10. Moher D, et al. The PRISMA Group. Preferred reporting items for systematic reviews and meta-analyses: The PRISMA statement. PLoS Med. 2009;6(7):1000097.

11. Munn Z, et al. The development of a critical appraisal tool for use in systematic reviews addressing questions of prevalence. International Journal of Health Policy and Management 2014;3(3):123-28.

12. JBI [Internet]. Manual for evidence synthesis, jbi data extraction form for experimental /observational studies. (2020). [cited by 05.12.2020] Available from: https:// wiki.jbi. global/ display /MANUAL /3.2.8+Data + extraction.

13. Becker FG, Passos EP, Moulin CC. Short-term effects of a hypocaloric diet with low glycemic index. Am J Clin Nutr 2015;102:136572.

14. Duval K, at al. The Obesity-fertility protocol: a randomized controlled trial assessing clinical outcomes and costs of a transferable interdisciplinary lifestyle intervention, before and during pregnancy, in obese infertile women. BMC Obes 2015;2:47.

15. Einarsson S, at al. Weight reduction intervention for obese infertile women prior to IVF: a randomized controlled trial. Hum Reprod 2017;32(8): 1621-30

16. Einarsson $S$, at al. No effect of weight intervention on perinatal outcomes in obese women scheduled for in vitro fertilization treatment. AOGS 2019;98:708-14.

17. Espinós JJ, et al. Weight decrease improves live birth rates in obese women undergoing IVF: a pilot study. Reproductive Bio Medicine Online [Internet] 2017; Oct [cited;35(4):417-424.]. Available from: https:// pubmed. ncbi. nlm. nih. gov/ 28 739335/.

18. Goldman RH, et al. Reproductive outcomes differ following roux-en-Y gastric bypass and adjustable gastric band compared with those of an obese non-surgical group. Obes Surg 2016;26(11):2581-89.

19. Grzegorczyk-Martin V, et al. IVF outcomes in patients with a history of bariatric surgery: a multicenter retrospective cohort study. Hum Reprod 2020; 35(12):2755-62.

20. Kaya Y, et al. The effect of health-promoting lifestyle education on the treatment of unexplained female infertility. EJOG 2016; 9667:1-6.

21. Kiel IA, et al. Women undergoing assisted fertilisation and high-intensity interval training: a pilot randomised controlled trial. BMJ Open Sport Exerc Med 2018;4(1):000387.

22. Milone $\mathrm{M}$, et al. Does bariatric surgery improve assisted reproductive technology outcomes in obese infertile women? Obes Surg 2017;27(8):2106-12.

23. Moran L, et al. Diet and IVF pilot study: Short-term weight loss improves pregnancy rates in overweight/obese women undertaking IVF. ANZJOG 2011;51(5):455-9.

24. Musella $\mathrm{M}$, et al. The potential role of intragastric balloon in the treatment of obese-related infertility: Personal experience. Obes Surg 2011;21(4):426-30.

25. Musella M, et al. Effect of bariatric surgery on obesity-related infertility. Surg Obes Relat Dis 2012;8(4):445-9.

26. Mutsaerts MAQ, et al. Randomized trial of a lifestyle program in obese infertile women. N Engl J Med 2016; 374(20):1942-1953.

27. Oers AM, et al. Effectiveness of lifestyle intervention in subgroups of obese infertile women: a subgroup analysis of a RCT. Hum Reprod 2016;31(12):2704-13.

28. Oers AM, et al. Cost-effectiveness analysis of lifestyle intervention in obese infertile women. Human Reproduction 2017;32(7):1418-26.

29. Palomba S, et al. Physical activity before IVF and ICSI cycles in infertile obese women: an observational cohort study. Reproductive BioMedicine Online [Internet] 2014;Oct [cited;29:72-9.]. Available from: https://www.rbmojournal.com/action/ showPdf?pii=S1472-6483\%2814\%2900137-0.

30. Rothberg A, et al. The Feasibility of a Brief, Intensive Weight Loss Intervention to Improve Reproductive Outcomes in Obese, Subfertile Women: A Pilot Study. Fertil Steril 2016;106(5):1212-20.

31. Sim KA, et al. Weight loss improves reproductive outcomes in obese women undergoing fertility treatment: a randomized controlled trial. Clin Obes 2014;4:61-8.

32. Adamo KB, et al. The Maternal Obesity Management (MOM) Trial Protocol: a lifestyle intervention during pregnancy to minimize downstream obesity. Contemp Clin Trials 2013;35(1):87-96.

33. Amiri M, Tehrani FR. Potential Adverse Effects of Female and Male Obesity on Fertility: A Narrative Review. Int J Endocrinol Metab 2020;18(3):101776.

34. Güler AE, et al. Spontan ve Yardımcı Üreme Tekniği ile Oluşan İkiz Gebeliklerin Perinatal Sonuçları. Gaziosmanpaşa Üniversitesi Tıp Fakültesi Dergisi 2016;8(4):256-62. 
35. Price $S$, et al. Health consequences for mother and baby of substantial pre-conception weight loss in obese women: study protocol for a randomized controlled trial. Trials 2018;19(1):248-61.

36. Jul Yi X, et al. A meta-analysis of maternal and fetal outcomes of pregnancy after bariatric surgery. Int J Gynaecol Obstet 2015;130(1):3-9.

37. Kwong W, Tomlinson G, Feig DS. Maternal and neonatal outcomes after bariatric ve risks, a systematic review and meta-analysis: do the benefits outweigh the benefits outweigh the risks? Am J Obstet Gynecol 2018;218(6):573-80.

38. Espinós JJ, et al. The Effect of Lifestyle Intervention on Pregnancy and Birth Outcomes on Obese Infertile Women: A Systematic Review and Meta-Analysis. Int J Fertil Steril 2020;14(1):1-9.

39. Lisonkova S, et al. Maternal Risk Factors and adverse birth Outcomes Associated with HELLP syndrome: a population-based study. BJOG 2020;127(10):1189-1198.

40. Zhu T, et al. Association between maternal obesity and Offspring APGAR score or cord pH: systemstic review and meta-analysis. Scientific Reports 2015;5:183-86. 